\title{
The Impact of Gender Composition on Team Performance and Decision-Making: Evidence from the Field ${ }^{*}$
}

\author{
Jose Apesteguia \\ Ghazala Azmat \\ Nagore Iriberri $^{\dagger}$
}

July, 2010

\begin{abstract}
We investigate whether the gender composition of teams affect their economic performance. We study a large business game, played in groups of three, where each group takes the role of a general manager. There are two parallel competitions, one involving undergraduates and the other involving MBAs. Our analysis shows that teams formed by three women are significantly outperformed by any other gender combination, both at the undergraduate and MBA levels. Looking across the performance distribution, we find that for undergraduates, three women teams are outperformed throughout, but by as much as 10pp at the bottom and by only $1 \mathrm{pp}$ at the top. For MBAs, at the top, the best performing group is two men and one woman. The differences in performance are explained by differences in decision-making. We observe that three women teams are less aggressive in their pricing strategies, invest less in $R \& D$, and invest more in social sustainability initiatives, than any other gender combination teams. Finally, we find support for the hypothesis that it is poor work dynamics among the three women teams that drives the results.
\end{abstract}

Keywords: Gender; Teams; Performance; Decision-Making. JEL Classification Numbers: D03; D21; J16.

\footnotetext{
* We are grateful to L'Oréal and StratX for their collaboration and assistance in this study. We thank Manuel Arellano, Manel Baucells, Vicente Cuñat, Rachel Croson, David Dorn, Gabrielle Fack, Robin Hogarth, and Kurt Schmidheiny for helpful comments. Ozan Eksi and Jacopo Ponticelli provided excellent research assistance. Financial support by the Spanish Commission of Science and Technology (ECO2008-06395-C05-01, ECO2009-12836, ECO2009-11213 and SEJ2007-64340), Fundación Rafael el Pino, the Barcelona GSE research network, and the Government of Catalonia is gratefully acknowledged. ${ }^{\dagger}$ Universitat Pompeu Fabra and Barcelona GSE. E-mails: jose.apesteguia@upf.edu, ghazala.azmat@upf.edu, and nagore.iriberri@upf.edu.
} 


\section{Introduction}

Gender differences and their impact on economic outcomes have attracted increasing attention, both in the media and in the economic literature. There is evidence for systematic differences in the origins of choice and behavior by gender; namely, in the preferences of men and women. Croson and Gneezy (2009), in a comprehensive and exhaustive review of the work on gender differences in economic experiments, summarize the findings as follows: "We find that women are indeed more risk-averse than men. We find that the social preferences of women are more situationally specific than those of men; women are neither more nor less socially oriented, but their social preferences are more malleable. Finally, we find that women are more averse to competition than are men."1

The gender difference in risk attitudes, social preferences and preferences over competitive environments, has important implications for the understanding of differences in economic and social outcomes. For example, in a study of a large group of US firms over the period 1992-1997, it was found that amongst the highest paid executives in these firms, only 2.5 percent of the executives were women and that these women earned around 45 percent less than their male counterparts (Bertrand and Hallock, 2001). In a similar vein, Bertrand, Goldin, and Katz (2010) show that although male and female MBAs have nearly identical earnings at the outset of their careers, their earnings soon diverge, with the male earnings advantage reaching almost 60 log points a decade after MBA completion. The persistence of the gender gap in labor market outcomes is partly attributed to differences in preferences between men and women (see Manning and Swaffield, 2008). Another example can be found in Development Economics. It has been suggested that a way to improve human development is to “empower” women. Miller (2008) shows that the promotion of gender equality by way of extending suffrage rights to American women led to an increase in investments in children, reducing child mortality between 8 and 15 percentage points.

The studies on gender differences are most commonly done at the individual level, despite the fact that important decisions in modern economies are often taken by groups or teams. Committees and boards, business-partners, and even industrial and academic research groups are only a few examples of group decision-making in the

\footnotetext{
${ }^{1}$ See also Andreoni and Versterlund (2001), Byrnes, Miller, and Schafer (1999), Charness and Gneezy (2007), Croson and Buchan (1999), Gneezy, Niederle, and Rustichini (2003), and Niederle and Vesterlund (2007).
} 
real-world. Interestingly, the recent financial crisis has brought media attention to the gender composition of boards, and its influence on the firms' performance. ${ }^{2}$ The extrapolation of the findings at the individual level to the group level is not, however, immediately apparent. It is well-known that groups have their own idiosyncrasy. For example, a widely documented phenomenon is group polarization, whereby groups make more extreme decisions than the average of the individual views in the group. ${ }^{3}$ Therefore, the influence of gender on group performance and decision-making deserves greater attention.

Dufwenberg and Murenb (2006) are a prominent exception in the experimental economics literature, studying the influence of gender composition on group decisions. They use a dictator game, where groups of three people divide a sum of money between themselves and a fourth person. They find that groups are more generous and equalitarian when women are the majority. They also find that the most generous groups are those with two men and one woman. In the field, Bagues and Esteve-Volart (2010) show that the chances of success of female (male) candidates for positions in the Corps of the Spanish Judiciary are affected by the gender composition of their evaluation committees. They find that female candidates have better chances of success the more males in the committees (see also Zinovyeva and Bagues, 2009). Delfgaauw et al. (2009) study the interaction between the managers' gender and the gender composition among the workers. They find that sales competition is effective only in stores where the store's manager and a large fraction of the employees have the same gender. Finally, there are also empirical papers in finance that document a positive relationship between gender diversity in boardrooms and company performance. However, reverse causality is a pervasive problem in these studies, since companies that perform better are quite likely to be companies that also focus more on the gender diversity of their boards (see Carter et al. 2003, Farrell and Hersch, 2005, and Adams and Ferreira, 2009).

In this paper, we explore the influence of the team gender composition on economic performance. We study a large online business game, played in groups of three: the L'Oréal E-Strat game. Teams play the role of a general manager of a beauty-

\footnotetext{
${ }^{2}$ See for example the article titled "Crisis gives women a shot at top corporate jobs" by Lamia Walker in the Financial Times on the $18^{\text {th }}$ of October of 2008, and the article titled "Mistresses of the Universe" by Nicholas D. Kristof in the New York Times on $7^{\text {th }}$ of February of 2009.

${ }^{3}$ See Stoner (1968). See also Sobel (2008) for a theoretical account and for references to the empirical literature. For other established differences between individuals and teams see, e.g., Charness and Jackson (2007) and Charness, Rigotti and Rustichini (2007).
} 
industry company, competing in a market composed by four other simulated companies. There are two identical competitions occurring in parallel, one involving undergraduate students and the other involving MBAs. The L'Oréal E-Strat game was designed to simulate real business decisions, and hence, teams must take decisions related to brand management, research and development $(R \& D)$, and corporate social responsibility initiatives. The incentives in the game are high. The winning teams receive a 10,000 euros prize, plus a paid trip to Paris. Perhaps even more importantly, winning candidates have the possibility of being hired by L'Oréal. Our database consists of the last three editions of the L'Oréal E-Strat business game, from the years 2007, 2008 and 2009, yielding a total of 37,914 participants, organized into more than 16,000 teams from 1,500 different universities that are located in around 90 different countries around the world.

L'Oréal E-Strat offers a unique setting to study the influence of the gender composition of teams on performance and on decision-making. First, it is played worldwide, by a large number of individuals, coming from a large number of different institutions. Second, there are two separate competitions, involving two different subject pools, undergraduate students and MBAs, that constitute two very relevant samples to study the influence of gender composition of teams. The former represents the subject pool of reference for the vast majority of experimental studies. This facilitates comparisons of established results at the individual level, with new findings that may emerge at the group level. MBAs are also relevant as they represent a unique and important sample. These are subjects that, with a high probability, will play a key role in real-world business management. Hence, it is relevant to understand how these subjects interact in groups, conditioning on the gender composition in teams. Third, we can study the effect of the gender composition on performance and on other important aspects such as specific business decisions. Fourth, as mentioned, the game aims to simulate the business environment as close as possible to the real-world and incentives are high. Finally, this study also offers an important advantage over existing empirical studies. In particular, here reverse causality is not a concern. Teams are formed before their performance and, even more importantly, teams remain fixed over the entire game. Therefore, the impact of the gender composition on performance that we identify is unequivocal.

Our analysis shows that teams formed by three women are significantly outperformed by any other gender combination, both at the undergraduate and MBA 
competitions. The magnitudes are sizable, about three percentage points for the undergraduates and about four percentage points for the MBAs. We show that the effect is robust after controlling for a number of important variables, such as the quality of the institutions, the combination of candidates' fields of study in the teams, and the geographical areas.

When we extend our analysis to consider the distributional effects, we find that the performance of the three women teams shows interesting variations along the distribution. In the undergraduate competition, while the underperformance of three women teams remains significant along the entire distribution of performance, it markedly decreases as we move to the right on the performance distribution. Among the lowest 10 percent, three women teams are outperformed by as much as 10 percentage points, while at the top 20 percent, three women teams are outperformed by only 1 percentage point. We also find suggestive evidence that the optimal gender composition along the whole distribution is that of two men and one woman, although the differences are not statistically significant. In the MBA competition, the performance levels of all the gender combinations are higher along the entire distribution, although the differences are not always significant. Interestingly, at the top 10 percent, the team composed of two men and one woman shows to be the optimal gender combination.

After establishing the differences in performance, we seek to understand which decisions drive these differences. First, we find that three women teams invest significantly less in R\&D, both in the undergraduate and MBA competitions. This is an important source of divergence in the performance of the different teams by gender composition, since R\&D is an important determinant of success in the game. A possible interpretation of these differences is that three women teams are more conservative in their management vision. That is, women teams seem to heavily weight the cost associated to $R \& D$ decisions, with respect to the improvement in the value of the firm. Second, teams differ in their decisions related to another crucial aspect for performance: brand management. Both, in the undergraduate and MBA competitions, three women teams show significantly lower profits. We identify an important difference in the pricing strategy that leads to these differences: three women teams are pricing their products higher than any other gender combination. That is, these teams are significantly less aggressive in their pricing strategies, and this has consequences on sales, profits, and ultimately on economic performance. Finally, we observe differences on decisions related to corporate social responsibility. We find that three women teams 
invest significantly more in social initiatives than any other gender composition, both at the undergraduate and MBA levels.

In our setting, teams are not exogenously formed. Since teams in important economic and business environments are rarely exogenously formed, this feature brings team formation closer to reality. The endogenous formation of teams raises the question of whether the differences we observe are the result of differences in individual abilities (by gender); sorting by ability type; or work dynamics. Using proxies that control for individual ability, we discard that differences in individual ability are driving the main results. In order to disentangle between the sorting-by-ability and work-dynamics hypotheses, we use an instrumental variable approach. We propose three different instruments that explain exogenous variation on initial team formation, which is on the margin, and more importantly, uncorrelated with ability. Our setting is ideal to evaluate the effects gender policies on real-world teams. Since the instruments use marginal switching in teams that are already formed, it is exactly the variation one would need to study, for example, changes in gender composition on boards. For the competition at the undergraduate level, the instrumental variable approach confirms our earlier findings that three girl teams perform worse than other gender compositions. For the competition at the MBA level, although our results are in-line with our earlier finding, the effects are no longer statistically significant. We find support for the poor work dynamics hypothesis rather than sorting according to ability, or differences in individual ability, to explain the underperformance of three women teams.

The organization of the rest of the paper is as follows. In section 2 we introduce the L'Oréal E-Strat game in detail. Section 3 is devoted to the presentation of the demographics in our data, both at the individual and team level. Section 4 establishes the main result on the effect of the gender composition on performance, as well as it checks for its robustness. Section 5 is devoted to the understanding of where the performance differences come from. In section 6 we address the issue of the team formation. Finally section 7 concludes.

\section{The Game: L'Oréal E-Strat}

\subsection{Overview of the Game}

The L'Oréal E-Strat game is one of the biggest online business simulation games. It was designed and developed by Strat-X for L'Oréal. The game was launched in 2000, and since then, there have been more than 250,000 participants, from more than 2,200 
institutions spread all over the world. It is open to all students in their final or penultimate year of undergraduate study, or studying an MBA, registered at a university anywhere in the world. Undergraduates and MBAs participate in separate competitions of the same game.

The game is played by teams of three members. Each of the teams plays the role of a general manager of a beauty-industry company, competing in a market composed by four other simulated companies. The game was designed to simulate real business decisions. In turn, teams make decisions that are related to $\mathrm{R} \& \mathrm{D}$, brand management and corporate social responsibility initiatives. In fact, games similar to L'Oréal E-Strat are used as an educational tool to teach managerial decision-making in business schools.

The rules of the game are clearly stated in the detailed introduction to the game, and participants have available a number of auxiliary documents to guide them through the game. Finally, incentives are very high.

\subsection{Rules of the Game}

The L'Oréal E-Strat is a web-based game and any registered undergraduate student in the final or penultimate year of study and any person taking part in an MBA program from anywhere in the world is eligible for participation. There are no restrictions on the field of study, gender, age, or geographical origin. Successful registration to the game requires teams to be composed of three members, where all team members are eligible. All team members must attend the same university, and must provide the following required information: name, official ID, age, gender, university, field of study, and country of origin. Teams that do not comply with these requirements are discarded.

There are two parallel competitions, one for undergraduates and one for MBAs; both competitions have the exact same rules. The L'Oréal E-Strat business simulation game is comprised of six rounds, plus a final round that is in a different format. In each one of these six rounds, teams compete in a market composed uniquely by the team itself and four other simulated companies. That is, the participating teams do not compete with one another in the same market. The main performance variable is the Stock Price Index (SPI). The SPI measures the market value of the company, as a consequence of team's decisions, as well as the decisions taken by the competing (simulated) firms. As such, the SPI is not only determined by current profits alone, but also by broader management decisions, such as those involving investments in R\&D or corporate social sustainability initiatives, that may be exploited in the future. 
The initial conditions are identical for all participating teams. In particular, all teams start with an SPI of 1,000. Subsequently, after decisions are taken in round one, the SPI is computed and only the best 1,700 participating teams (in terms of their SPI), are selected to pass to the second round, taking into account country and zone quotas. ${ }^{4}$ In this paper, we will use data from the first round only, for the reasons explained in Section 2.4. The game continues in the same way for rounds two to five. In round six, the semi-finals, the surviving teams submit their management decisions, as well as a business plan. In the final round, the surviving 16 teams, 8 for the undergraduate and 8 for MBA competitions, each representing a geographical zone, are invited to Paris. Teams present their business plan in front of a jury, composed of professionals and academics. The winning teams, one undergraduate team and one MBA team, are awarded with a 10,000 euro prize each. ${ }^{5}$ More importantly, they have the opportunity to meet high profile professionals in L’Oréal, and some of them are offered employment opportunities.

\subsection{Management Decisions}

All participants are provided with instructions that include the relevant information for successful participation. ${ }^{6}$ The instructions include information on how to download and install the e-Strat software, information on the rules, a careful description of the industry in which they will compete, detailed information on the type of decisions that teams must take, and the type of information they will receive in each round. A proper understanding of the instructions requires a good deal of time and effort.

We distinguish between three different types of decisions that teams must undertake in the first round. These decisions generate what we refer to as midway outcome variables. These midway variables then affect the final, and most important, outcome variable, the SPI. A summary of the decisions and midway outcome variables is given in Table 1.

First, teams make decisions regarding the investment in R\&D. Teams are told that they have an $R \& D$ department, where researchers discover two new formulae that may be used to create new brands. Teams must then make two main decisions with respect to

\footnotetext{
${ }^{4}$ All participating teams are divided into eight different geographical zones, according to the location of the university. The selection of the surviving teams from one round to the next is based on SPI, controlled by geographical zone, in a way that every zone must represent at least a $7 \%$ of all surviving teams and no country can represent more than $15 \%$ of all surviving teams.

${ }^{5}$ The prize of 10,000 euro is to be spent in travel of the winning team members' choice.

${ }^{6}$ The instructions from 2008 editions are available in the web appendix.
} 
the formulae created by the R\&D department. First, teams must decide whether or not to invest in each of the created formulae, that is, whether to invest in zero, one or two formulae. Second, if they decide to invest in formulae, they must specify the amount that they wish to spend on each of them. Together these decisions form the midway outcome variables, total R\&D investment.

Second, teams must manage their brands. In the first round, all teams start with the same two brands. Brands differ in their characteristics in a way that they are targeting a specific customer profile. In particular, participants know whether the brand is targeting women who are high earners; affluent families; medium income families; low income single women; or low income families. In each edition, there are different brand targets for each of the two brands. The two main decisions that teams must take are the price and the production level for each of the two brands. These, in turn, influence the main midway outcome variables regarding the brand management, which are composed of sales, revenues, production costs and inventory costs. Finally, these variables determine profits.

Third, teams must decide how much to invest in social and environmental initiatives. The former includes initiatives such as having health programs or continuous learning plans for employees. The environmental initiatives include actions, such as using renewable raw materials, reducing water consumption, or having safety and health compliant plants. Using the teams' investment in these initiatives, the simulation creates "Social Sustainability" and "Environmental Sustainability” indexes, which are the main two midway outcome variables in this area.

Overall, the decisions made in all three of these areas affect the market value of the company, and this is incorporated in the main performance variable, the SPI.

\subsection{Data and Relation between Managerial Decisions and Performance}

Our database consists of the last three editions of the L'Oréal E-Strat; from the years 2007, 2008 and 2009. This comprises of a total of 37,914 participants from 1,500 different universities, located in about 90 different countries around the world. We will use only the decisions and performance outcomes from the first round. The starting situation in round one is exactly the same for all teams in the L'Oréal E-Strat game, and therefore, the decisions and associated performances in the first round are fully comparable across teams. This is not the case for round two, since teams that progress to the later rounds take decisions that have heterogeneous consequences on 
performances because of their game history (i.e., performance and decisions in previous rounds). Hence, for a clean and even-handed comparison across teams, we will only focus on the first round's decisions and performance.

Success in the L'Oréal E-Strat business game, represented by high values in SPI, is determined by the midway outcome variables and ultimately by teams' management decisions. In the remaining part of this section, we will elaborate on the relationship between decision variables, midway outcome variables and the final performance variable, the SPI. This will facilitate the understanding and interpretation of the team differences in performance, which we will study in sections 4,5 and 6 . We look at the associations across variables in two ways.

First, we show that there exists a relationship between the midway outcome variables and the SPI. We use a simple regression analysis, where the final performance measure, the SPI, is regressed on the midway decision variables, separately for the two competitions, undergraduates and MBAs. The results are shown in Table 2. The first two columns report the results when we include all the midway outcome variables simultaneously, while the rest of the columns separately show the regressions for each midway outcome variable. The results show that for both competitions, all the midway outcome variables are positively and significantly related with SPI. More importantly, they show that there are large differences in the importance of each variable. Looking at the magnitude of the coefficients and at the R-squared, this table shows that, not surprisingly, midway outcome variables, such as $R \& D$ investment and profits have a higher order of magnitude than those related to social or environmental initiatives. Most of the variation in SPI is explained by the variation in both profits and in R\&D investment, and to a less extent by the variation in investment in social and environmental initiatives. In other words, a high SPI value is mainly due to high profits and investment in $\mathrm{R} \& \mathrm{D}$, and corporate social responsibility decisions play a smaller role.

Second, we examine the relationship between decisions and performance by comparing the ex-post decisions and performance of the top and bottom performing teams. In particular, we compare the top 10 percent with the bottom 10 percent. Table 3 reports the mean for each of the decisions, midway outcomes, and the SPI, separately for the top and bottom 10 percent teams. Since the brands change in the different editions, we report the means separately for each of the three editions, as well as for the undergraduate and MBA competitions. Columns 3, 6 and 9 show the $p$-values for the 
one-way ANOVA test of equality of means across the top and bottom 10 percent teams' decisions and outcome variables.

From Table 3, we can clearly see that there are sizeable and highly significant differences in the decisions and in the outcome variables of the top 10 percent teams, when compared to the decisions and outcome variables from the bottom 10 percent teams, both in the undergraduate and MBA competitions.

As for the midway outcome variables, top and bottom performing teams differ in all of them, with few exceptions. The top 10 percent teams invest more in $R \& D$, although not always significantly; they have significantly higher sales, revenues and profits; and significantly fewer inventories. Finally, the top 10 percent teams have significantly higher environmental sustainability index, while there are no clear patterns in the social sustainability index.

As for the specific decision variables, again top and bottom performing teams differ in most of them. In every case, the average number of formulae developed by top 10 percent teams is higher, although not always significant. This is likely to be a consequence of there being few choices (i.e., zero, one or two). The pricing and production strategies are also systematically and significantly different. For high-end brands (brand 2 in 2007 and 2009), the top 10 percent set significantly lower prices, while for low end brands (brand 1 in 2007 and 2009, and both brands in 2008), the top 10 percent set significantly lower prices, with the exception of brand 1 in 2009. Top performing teams also produce significantly more for all brands, except for brand 2 in 2008.

\section{Demographics}

In this section, we look at the main demographic variables, both at the individual and team level.

At the individual level, we can observe participants' age, gender, field of study, country of origin, and the university where the student is currently enrolled. Table 4 reports female and male participants' characteristics, separately for undergraduates and MBAs.

First, undergraduates and MBAs differ on a number of expected dimensions. MBAs are older, study more Business related subjects and less Economics or Science related subjects. Also, the MBAs are more likely than undergraduates to study in foreign institutions. There are also some differences in terms of the country of origin. In the 
subsequent analysis, we will study the MBA and undergraduate competitions separately.

Second, looking at differences between male and female participants, in the undergraduate competition there are a total of 12,759 women and 14,525 men, while in the MBA competition the numbers are 3,934 women and 6,697 men. Participation, by gender, in the undergraduate competition is comparable (47\% women and 53\% men), while in the MBA competition, men are more prevalent (37\% and 63\%). These proportions do not represent a peculiarity of the L'Oréal E-Strat but are representative of the actual gender ratios in undergraduate and MBA studies. ${ }^{7}$ When comparing male and female participants, it can be also seen from Table 4 that women are slightly younger than men, both at the undergraduate and MBA level, and that undergraduate women study slightly more business and less sciences than undergraduate men.

The L'Oréal E-Strat game is played by teams of three people. Therefore, we are interested in group level characteristics. In the paper, the main variable of interest is the gender composition of these teams, such that we classify teams into four categories: teams formed by all males; all females; two males and one female; or one male and two females. We denote the team composition by $\mathrm{Mx}$, where $x$ is the number of men in a team and $(3-x)$ females. Table 5 reports descriptive statistics at the team level, divided by their gender composition.

In the undergraduate competition, the distribution of teams by gender composition is $19 \%, 27 \%, 30 \%$, and $24 \%$ for M0, M1, M2, and M3 teams, respectively. The corresponding distribution in the MBA competition is $11 \%, 23 \%, 33 \%$, and $33 \%$. Interestingly, given the proportions of men and women in the two competitions, these distributions look remarkably similar to the distributions that one would get if the formation of teams had been random at the gender level. That is, with a 47-53 gender ratio in the undergraduate competition, the random composition of teams by gender is $21 \%, 23 \%, 26 \%$, and $30 \%$; very close to the observed one. In the MBA competition, with a 37- 63 gender ratio, the corresponding random distribution is $9 \%, 16 \%, 28 \%$, and 47\%; somehow further from the one observed one but still very close.

At both the undergraduate and MBA levels, the four different types of teams look very similar in terms of their characteristics. We do see that, at the undergraduate level,

\footnotetext{
${ }^{7}$ For undergraduates, according to the World Development Indicators database (World Bank, 2008), the average worldwide ratio of female to male enrollments in tertiary education is 105.3. For MBAs, Bertrand, Goldin, and Katz (2010) report that the US average of MBAs earned by women in the last two decades is about 40 percent.
} 
M0 teams are formed by students with less science as field of studies, consistent with gender differences at the individual data. Also, in terms of the geographical location of the institution, there are some small differences both, at the undergraduate and MBA level. Finally, it is interesting to note that there is more field diversity in mixed teams, M1 and M2 teams, than in all men or all women teams, i.e., in M3 and M0 teams, both in the MBA and in the undergrad teams. In the analysis that follows, we will control for all of these characteristics.

\section{Does the Gender Composition of Teams Matter for Performance?}

\subsection{The Overall Effect}

We start our analysis by looking at the main performance variable, namely the SPI. In what follows, we will use standardized SPI. ${ }^{8}$ The main objective of the paper is to understand whether the gender composition of the team has any effect on performance. In order to do so, we estimate the following equation by Ordinarily Least Squares, separately for the undergraduate and MBA competitions:

$$
Y_{i}=\alpha+\beta_{1} \mathrm{M}_{i}+\beta_{2} \mathrm{M} 2_{i}+\beta_{3} \mathrm{M} 3_{i}+X^{\prime} \theta+\delta_{j}+\gamma_{t}+\varepsilon_{i j t}
$$

where the dependent variable $Y_{i}$ denotes the standardized SPI of team $i$. The gender composition of the teams is captured by the variables M1 to M3. M1 takes the value of 1 when the team has one man and two women and 0 otherwise, M2 takes the value of 1 when the team has two men and one woman and 0 otherwise, and M3 takes the value 1 when the teams is composed of three men. The omitted category, to which these variables are compared, refers to teams with three women, namely M0 teams. $X$ is a vector of control variables that include the mean age of the team members, field of study of the team members, field diversity among the team members, country diversity among the team members, and institution diversity, which measures the diversity between the nationality of the team members and the country in which the institution is located. ${ }^{9}$ In addition, we control for geographical areas or zones, $\delta_{j}$, and year (or edition) fixed effects $\gamma_{t}$. Finally, we cluster the standard errors at the zone and year level.

\footnotetext{
${ }^{8}$ SPI values are standardized because the variable itself has no intrinsic meaning and the standardization makes the interpretation more intuitive. We standardize the SPIs for each competition in a given year by subtracting the minimum SPI from the SPI and dividing this by the difference between the maximum and minimum SPI.

${ }^{9}$ See the notes in Table 5 for the definitions of these variables.
} 
Table 6 reports the results from estimating equation (1). The first two columns in the table show the effect of gender composition of teams on SPI for the undergraduate and MBA competitions, respectively, without controlling for other characteristics. Columns 3 and 4 include the control variables, $X^{\prime}$, as well as the year and zone fixed effects. Overall, we find that the teams composed of three women are significantly outperformed by any other gender composition, both at the undergraduate and MBA levels. In the undergraduate competition, without controls, we see that the teams with one man, two men and three men significantly outperform three women teams by 0.0167 (2.3pp), 0.019 (2.6pp) and 0.0103 (1.4pp), respectively. The corresponding difference at the MBA level are 0.0247 (3.6pp), 0.0323 (4.7pp) and 0.0452 (6.6pp), respectively.

With controls, the differences persist. We find that teams with one man, two men and three men outperform three women teams by approximately 2.7pp, 3.6pp and 3.0pp, respectively, in the undergraduate competition. The corresponding percentages at the MBA level are 3.2pp, 5.1pp and 4.6pp. All these differences are significant at conventional levels, except in the MBA case for the relationship between M1 teams and M0 teams, which is significant only at the $11 \%$ level. In addition, there is some suggestive evidence that teams with one woman and two men are the best performing teams; however, we do not find statistical significance for this. With respect to the control variables, we can see that it is important to control for year fixed effects, since the different editions had some variations. Other variables, such as age at the MBA level are also important in explaining the differences in SPI. However, when we interact age with team's gender composition, there is no significant difference, showing that age is affecting all gender composition teams in an analogous manner.

We, therefore, conclude that the underperformance of three women teams is present at both, the undergraduate and MBA competitions. In fact, the magnitudes are slightly higher at the MBA level. Also, interestingly, looking at the point estimates, there is some suggestive evidence that the best performing gender combination is the mixed team with two men and one woman, both at the undergraduate and MBA levels, although it is not statistically significant at conventional levels. 


\subsection{Robustness of the Overall Effect}

We now check for the robustness of the overall effect identified in section 4.1. In particular, we study the influence of the specific combination of different fields of study by the team members, and the quality of the institution attended by the team members.

We start by analyzing the influence of the composition of fields of study in teams. In the previous section, we controlled for the presence of a field of study in the team. We now take one step further and analyze whether particular combinations of fields of study become relevant. It might be the case that three women teams show significantly different field compositions than other teams, and this is the main cause of the effect. In order to address this possibility, we construct dummy variables that identify every possible combination of different fields of study. For example, "EBS" is a dummy variable that takes the value of 1 when the team is composed of an Economics student, a Business student and a Science student; and 0 otherwise. The first two columns of Table 7 report the results of estimating equation (1) with all the other control variables used in the previous section, but substituting the variables referring to the presence of fields of study with the ones referring to the specific combination of different fields of study in the team. We find that the main result is robust to this additional control, both at the undergraduate and MBA level. Every gender combination significantly outperforms M0 teams. Furthermore, the coefficients are very similar to those obtained in the previous section, and so are the significance levels. ${ }^{10}$

Second, we control for the quality of the institution. One potential explanation for three women teams being outperformed is that the all women teams, when compared with the other team compositions, are attending a university or business school that is of a poorer quality, thus reflecting a low ability level of the team members. We address this point in two ways. First, we use measures of institutional quality that are external to the L'Oréal E-Strat Game. Namely, we use the 2009 Ranking Web of World Universities as a measure of the quality of the school for the undergraduate competition and the 2009 Financial Times Ranking of MBAs for the MBA competition. ${ }^{11}$ These rankings contain around $85 \%$ of the universities and $70 \%$ of the business schools in our database. Columns 3 and 4 in Table 7 report the results of estimating (1) with all the

\footnotetext{
${ }^{10}$ Now the difference between M1 and M0 teams in the MBA competition becomes significant at the $10 \%$ level.

${ }^{11}$ http://www.webometrics.info/top6000.asp and http://rankings.ft.com/businessschoolrankings/globalmba-rankings
} 
controls we used in the previous section, adding the ranking of the schools. We again see that the results are robust to the inclusion of this additional control, and the coefficients and significance levels remain almost the same.

Finally, we control for the institutional quality by including institution fixed effects. Since we observe many of the same institutions over the years, by adding the fixedeffect, we can control for the quality of each institution, as well as any other schoolspecific characteristic. The last two columns in Table 7 report the results of estimating equation (1) with all the controls in the previous section and including school fixed effects. Once more, we see that the finding that three women teams are outperformed by teams of any other gender composition is robust to the addition of this control. Furthermore, the magnitude and the significant levels remain the same.

\subsection{Distributional Analysis}

Our estimation analysis so far has focused on the mean effect of the influence of the gender composition of teams on SPI. However, it is also important to understand how the effect of the team's gender composition on SPI varies at different points of the performance distribution. In order to do so, we estimate quantile regressions using equation (1). The results are shown in Figures $1 \mathrm{a}$ and $1 \mathrm{~b}$, where we plot the coefficients for the different gender compositions, M1, M2 and M3, relative to the omitted category, M0, for each quantile, for undergraduates and MBAs, respectively. Thus the distance between the coefficients, with respect to the horizontal axis, reflects the distance with respect to M0 teams. Table 8 reports the corresponding regressions for the point estimates shown in the figures.

We start by analyzing the undergraduate case. Figure 1a and Panel A of Table 8 show that M0 teams are significantly dominated by teams with any other gender combination throughout the entire performance distribution. Interestingly, we see large disparities in the magnitudes of these effects. Most notably, the largest differences come from the bottom of the performance distribution, and they decrease monotonically along the distribution. While for teams whose performance is at the bottom 10 percent of the distribution, the three women teams are outperformed by $7.9 \mathrm{pp}, 9.9 \mathrm{pp}$ and $8.0 \mathrm{pp}$, by M1, M2, and M3 teams, respectively; for teams whose performance is at the top 10 percent of the distribution, the three women teams are outperformed by less than 1pp.

These results are informative for three important reasons. First, we see that the underperformance of three women teams is persistent throughout the entire distribution. 
Second, there is a great deal of heterogeneity in the disparity. In particular, it is important to stress that the high performing three women teams are much more similar to teams of any other gender combination. Third, the point estimates suggest that the mixed team, composed of two men and one woman, has the highest performance levels all over the distribution. This is in-line with our findings in section 4.1, when studying the overall effect. However, these differences are not significant at conventional levels, providing only suggestive evidence.

Figure $1 \mathrm{~b}$ and Panel $\mathrm{B}$ in Table 8 report the results for the MBAs. The coefficients for all the gender combinations, with respect to M0, are positive along the entire distribution, suggesting that three women teams are underperforming. Interestingly, unlike the undergraduates, the differences are less robust across the distribution and are often insignificant, especially in the bottom half of the distribution. Furthermore, at the top 10 percentile, we see that the only gender composition performing significantly better than three women teams is the team composed by two men and one woman. This again provides evidence in favor of gender diversity at the top of the performance distribution.

\section{Understanding the Differences in Performance: The Decision Analysis}

In the analysis so far, we have shown that all women teams are significantly outperformed by teams with any other gender composition. We now proceed to understand these differences in performance. In this section, we analyze the managerial decisions that teams undertake, and identify the differences. In particular, we study team decision-making on R\&D, brand management, and corporate social and environmental responsibility initiatives. In the analysis that follows, we estimate equation (1) for each of the three decision categories, including all the controls as in section 4.1.

\subsection{Investments in $R \& D$}

Each team has an R\&D department that creates two new formulae, formula A and formula B. These formulae should be interpreted as innovations that, if developed, can be used to create new brands or improve the existing ones. Teams have two main decisions to take with regard to the formulae created by the R\&D department. First, teams must decide whether or not to invest in each of the created formulae. Second, if they do decide to invest in formulae, they must specify the amount that they wish to spend on each of them. We refer to this expenditure decision as the R\&D investment. 
We analyze whether teams with different gender compositions make significantly different decisions regarding the number of formulae to develop and the investment in R\&D. The results are shown in Table 9.

The first two columns of Table 9 show the estimates for the number of formulae. Both, at the undergraduate and MBA levels, all gender combinations have significantly more formulae than M0 teams. The remaining columns in Table 9 show the estimates for the standardized R\&D investment. ${ }^{12}$ Since there are significant differences in the developed number of formulae, we look at the $R \& D$ investment separately for the three cases; those teams creating only formula $\mathrm{A}$, those creating only formula $\mathrm{B}$, and those creating the two formulae. Table 9 shows that when we condition on teams creating only one formula, the gender composition of the team is mostly insignificant. However, among those teams that do decide to invest in two formulae, we again see that all teams invest more in developing those two formulae than M0 teams.

Overall, we observe that three women teams create significantly fewer formulae and, moreover, even when they do create two formulae, they invest significantly less in $R \& D$. Recall from Table 2 that $R \& D$ investment has a sizeable positive influence on SPI. This is very informative, as it helps us to understand why M0 teams are outperformed by teams of any other gender composition. The underperformance of three women teams is, in part, explained by their behavior related to $R \& D$, such that women teams invest too little in R\&D. A possible interpretation of these differences between the teams is that all women teams are more conservative in their management vision. That is, all women teams seem to overweight the cost associated to R\&D decisions, with respect to the improvement in the ultimate value of the firm.

\subsection{Brand Management}

In this section, we start by analyzing the impact of teams' gender composition on the midway outcome variables that are directly determined by brand management. We start with an analysis at the aggregate level, looking at variables such as profits, revenues, costs, sales, and inventories. ${ }^{13}$ We then break-down the aggregate analysis to study each of the brands separately.

\footnotetext{
12 Investment in R\&D has also been standardized. We standardize the R\&D investment for each competition in a given year by subtracting the minimum from the current value and dividing this by the difference between the maximum and minimum R\&D investment.

${ }^{13}$ We standardize the profits, revenues, costs, sales and inventories, with respect to their maximum and minimum values for each category and year, as we did for the SPI and the R\&D investment.
} 
The main outcome variable related to brands is profits. Accordingly, we first analyze whether the level of total profits earned by teams varies across the different gender compositions. In columns 1 and 2 of Table 10, we report the profits at the aggregate level, for undergraduates and MBAs, separately. Both at the undergraduate and MBA levels, we find that every gender composition achieves significantly higher profits than M0 teams. When we separate the profits into revenues and production costs, we see that the difference is largely related to differences in revenues but not in production costs. The M1, M2 and M3 teams attain significantly higher revenues than M0 teams, but there are no significant differences in production costs. Consistent with the results on profits, revenues, and production costs, Table 10 also shows that all teams produce more than the M0 teams but they also sell more; resulting in lower inventory costs. These differences highlight that the underperformance of all women teams is also related to their brand management. We see that M0 teams are choosing worse selling strategies than teams with other gender combination.

To understand the differences in their selling strategy, we now turn our attention to the analysis of brand management at the brand-type level. Consumers are divided into five different segments, which differ in size, price sensitivity, and preferences. Teams are provided with this information in their instruction manuals. The five segments, ordered by their income (highest to lowest) and price sensitivity (lowest to highest), are: (i) high-earners, (ii) affluent families, (iii) medium income families, (iv) singles, and (v) low income families. Accordingly, brands differ in terms of the type of consumers to which they are targeted. In the three editions of the game that comprise our database, there were four different brand-types: (a) high-income (edition 2007), (b) mediumincome families (2009), (c) singles (2008 and 2009), and (d) low-income (2007 and 2008).

Columns 2-5 in Table 10 report the analysis at the brand-type level. We see that for undergraduates, the differences identified at the aggregate level, in terms of profits, revenues, sales and inventory costs, are concurrent only for brand-types (b) and (c); the intermediate brand types. When we analyze the other brands, the high-income and lowincome brand types, there is almost no difference across teams. We next consider the differences in teams' pricing strategies. We see that it is precisely with brand-types (b) and (c) that M0 teams choose significantly higher prices than all the other gender composition teams. This pricing strategy results in significantly lower revenues (and profits) for the M0 teams, and, in turn, this also explains why M0 have significantly 
higher inventory costs. We can interpret such a pricing strategy by M0 teams as being less aggressive than the rest of the teams. In other words, teams other than M0 choose a more aggressive pricing strategy that undercuts their simulated competitors than all women teams.

The analysis at the MBA level, when disaggregated by brand-types, does not show consistent and clear significant differences. This is likely to be the result of a reduction in the number of observations, and hence the significance levels are lower. However, the magnitudes and signs are comparable to those found at the aggregate level.

\subsection{Corporate Responsibility}

Teams have the option to invest in corporate responsibility decisions, as measured by two indices, the Social Sustainability Index (SSI) for social initiatives, and the Environmental Sustainability Index (ESI) for environmental initiatives. Social initiatives involve improving the working conditions, such as investing in health programs for the employees, or continuous learning. Environmental initiatives are oriented towards improving the environment with investments that reduce water and energy consumption, or promote the use of raw materials from natural, renewable sources. In this section, we study whether the gender composition of the team has any effect on the corporate social and environmental responsibility decisions, as measured by the standardized SSI and ESI indices. Table 11 reports the results.

With regard to social initiatives, we find that three women teams invest significantly more in social initiatives than any other gender composition, both at the undergraduate and MBA level. These differences are as large as 11pp in both levels. All comparisons are significant, except in the M2 case for MBAs where the coefficient goes in the same direction than all others, but it is not significant at conventional levels. In columns 3 and 4, on the other hand, the gender composition of the teams does not appear to influence decisions related to environmental initiatives.

Hence, gender composition seems to matter for the type of decisions taken regarding the social initiatives. In section 2.4 we observed that SSI is positively related to SPI. However, we also observed that the influence on SPI of the social sustainability initiatives are of an order of magnitude lower than other midway outcome variables like profits or investment on R\&D. This shows that, although M0 teams show significantly higher values in SSI, this has little impact on the final and main outcome variable, on SPI. 


\section{Team Formation: Ability, Sorting, and Work Dynamics}

We have shown that three women teams are outperformed by teams of any other gender combination. In our setting, teams are formed endogenously. This adds realism to the question we are interested since the vast majority of teams emerge endogenously in the market place. At the same time, different competing explanations may account for the result. We consider three explanations: (i) gender differences in ability, (ii) gender differences in sorting into teams related to ability, and (iii) gender differences in team work dynamics. In this section, we will analyze each of these three potential explanations in detail and we will implement an instrumental variable (IV) approach to distinguish between explanations (ii) and (iii). The IV will allow us to identify the mechanism that drives the main results, i.e., why all women teams perform worse than the other team gender compositions.

First, one may consider the idea that there are differences in ability between participating men and women. In other words, it could be the case that the distributions of ability between those men and those women that decide to participate are different, and this translates into differential ability skills in teams by gender composition. Although we do not directly observe individual ability, we can use observable characteristics, such as age, which may reflect experience; field of study; and quality of the university attended, as proxies for individual ability. When controlling for all of these factors, including the university fixed effects (see Tables 6 and 7 and the discussion in sections 4.1 and 4.2), we continue to find that all women teams are outperformed by other gender compositions, both at the undergraduate and MBA competitions. This suggests that the differences in ability between women and men are not the main driving force. Finally, one may conjecture that if differences in ability between participating men and women would be the main driving force, one would expect to have a monotonic relation between performance and number of males, which is clearly not the case; neither at the undergraduate nor the MBA competitions.

A second potential explanation is that the relationship between ability and sorting into teams may be different, depending on the gender. Suppose that the distribution of ability at the individual level in men and women are identical, but low ability women are more likely to sort into three women teams than are low ability men into all men teams. We can evaluate whether individuals differ on observable characteristics, depending on the team they sort into. From Table 12 we see that, overall, women and 
men in the different teams look remarkably similar. At the MBA level, there are some small differences, e.g. women who sort into teams with more men are slightly older. However, when we control for these differences in the analysis in section 4 our main findings hold. It could be that the differences in ability, which are related to sorting into teams, are unobservable. We will address this issue below.

A third potential explanation for our results is that teams have different work dynamics, depending on their gender composition. In other words, suppose that both, males and females are not different in their ability and furthermore the sorting patterns are also analogous between men and women. This would generate teams that are comparable in the ability of their individuals but their economic performance may still differ if there are differences in team work dynamics.

In order to distinguish between the second and the third explanations, we need exogenous variation, a change on the margin, that has an effect on the initial team formation, i.e., being in an all women team or not, but that is uncorrelated with ability. We do this by using an instrumental variable (IV) approach. We use three different IVs, which are ideal for our setting: (i) gender ratios among the participating students at the university level, IV1 (ii) year-on-year change in the gender ratios among the participating students at the university level, IV2, and (iii) gender ratios among university students at the country level, IV3. Since we use marginal changes on teams that are already formed, this approach is ideal for evaluating changes in the gender composition of teams in the real-world. When using these IVs, if we continue to find that three women teams are outperformed, we would find support for the work dynamics hypothesis. We now elaborate on each of the IVs.

A good instrument should be correlated with the endogenous variable (i.e., three women in a team) and uncorrelated with the error term. The gender composition at the university level, IV1, does not affect team performance directly, but may well affect the probability of being in an all women team. The intuition behind this approach is as follows. The gender composition at the university level affects who will work with whom, such that when there are few women in the university, as one would expect, they will be more likely to work with men than among themselves. In turn, there should not be sorting by ability because people will simply be working with who is around.

One concern may be that universities with more females or males are somehow different, relating to ability, such that the instrument in levels described above, IV1, may be compromised. For this reason, given we have three years of data, we use the 
panel element of the data and use the change from one year to the next in the gender ratios at the university level (IV2). This way, we can eliminate the university level fixed effect, ruling out any concern about university specific characteristic. Finally, the third instrumental variable, IV3, uses variation in the gender ratios among university students at the country level. ${ }^{14}$ This allows us to have variation that comes from an external source, away from university students who are participating in the L'Oréal E-Strat game. A potential drawback of this third instrument is that we do not have data on all the countries that are participating in the L'Oréal E-Strat game.

Table 13 shows the second stage results from IV1, IV2 and IV3 for the variable of interest, M0 teams. ${ }^{15}$ In the first stage, each instrument is individually significant at the $1 \%$ or $5 \%$ level, with respect to M0. In columns 1 and 2, for comparison, we include the OLS estimate for this variable. The results show that being in an all woman teams implies a lower performance (3pp lower for undergraduates and 4pp lower for MBAs). This is fully in-line with our earlier analysis.

Columns 3 and 4 present the results for IV1. The direction of the coefficient stays the same as for the OLS results but the size of the magnitude is somewhat larger. The effects are significant for undergraduates at the $5 \%$ level but only at the $14 \%$ for MBAs. Columns 5 and 6 present the results for IV2. We can see that results for undergraduates are similar to those found using OLS and IV1. However, again, the results for the MBAs are not significant and the coefficient changes direction. This is likely to be the result of the smaller sample and there being less variation in gender ratio change when using the year-on-year change. Finally, in columns 7 and 8, we show the results for IV3. For both, the undergraduate an MBA competition, the coefficient continues to be negative but it is only significant for the undergraduates. It is likely that, since we are using cross-country ratios for university entry, the instrument is less applicable for entry into MBAs. This may explain why we do not see significance at the MBA level.

Overall, given we find very similar results using the IV approach, these results offer support for the team dynamics hypothesis, rather than the sorting hypothesis. In particular, this is the case for the undergraduate competition. For the MBA competition, the evidence is economically but not statistically significant.

\footnotetext{
${ }^{14}$ We use the ratio of female to male enrollments in tertiary education from the World Development Indicators database, World Bank, 2008.

15 Since we do not have an individual IV for each possible team composition, we cannot use the categorical separation as we did in the earlier analysis. However, since there are no differences in performance among the other team compositions, the indicator variable is viable.
} 


\section{Conclusions}

In this paper, we have investigated the influence of the team gender composition on team economic performance and decision-making. We have used a unique data set, the L'Oréal E-Strat game, which is one of the largest and most reputed online business games, to shed light on the importance of gender effects at the team level.

We find that teams formed by all women are significantly outperformed by all other gender combinations at the undergraduate competition by 3pp, and at the MBA competition by 4pp. In the undergraduate competition, the effect is significant throughout the performance distribution, the differences decreasing with performance. At the bottom 10 percent the differences are as large as 10pp. These differences are decreasing, and at the top 10 percent of the distribution, three women teams are outperformed by only 1pp. Hence, high performing three women teams are much more similar to teams of any other gender combination. In the MBA case, although three women teams perform worse than the other teams in the entire distribution, the differences are not always significant.

Interestingly, both in the mean and distributional analysis, teams composed by two men and one woman consistently perform better than the other teams, although the differences are not always significant. For the top 10 percent of MBA teams, however, teams composed of two men and one woman are significantly the best.

When we investigate the differences in decision-making, we are able to understand why the three women teams perform worse than the other team gender compositions. First, three women teams invest significantly less in $R \& D$ than any other gender combination. This may be due to women teams being markedly more conservative in their management vision. Second, we show that three women teams follow different pricing strategies. All women teams are less aggressive in their pricing strategies, choosing prices that are significantly higher, and this has consequences on sales, profits, and ultimately on economic performance. Finally, we also find that three women teams invest significantly more in social initiatives than any other gender composition.

In our setting, teams form endogenously, and hence, there are different potential explanations for the differential performance levels we observe. In order to understand the mechanism behind the results, we have used an instrumental variable approach. In this analysis, we find evidence supporting the explanation that it is the poor work dynamics among three women teams, rather than sorting into low ability teams, which 
drives the low performance of three women teams. The evidence is clearly significant for the undergraduates but only suggestive for the MBAs.

The main finding of this paper, which is that all women teams are significantly outperformed by any other gender combinations, deserves further research. We hope that this paper will promote future empirical research on this question, which is of great relevance when understanding the functioning of organizations.

\section{References}

Adams, B. R. and D. Ferreira (2009) "Women in the Boardroom and their Impact on Governance and Performance,” Journal of Financial Economics, 94, 291-309.

Andreoni, J. and L. Vesterlund (2001) "Which is the Fair Sex?" Quarterly Journal of Economics, 116:293-312.

Bagues, M. F. and B. Esteve-Volart (2010) "Can Gender Parity Break the Glass Ceiling? Evidence from a Repeated Randomized Experiment," Review of Economic Studies, forthcoming.

Bertrand M, C. Goldin, and L. F. Katz (2010) "Dynamics of the Gender Gap for Young Professionals in the Financial and Corporate Sectors," American Economic Journal: Applied Economics, 2(3).

Bertrand, M. and K. Hallock (2001) "The Gender Gap in Top Corporate Jobs,” Industrial and Labor Relations Review, 55-1, 3-21.

Byrnes, J., D. Miller, and W. Schafer (1999) “Gender Differences in Risk Taking: A Meta-Analysis,” Psychological Bulletin, 75, 367-383.

Carter, D., Simkins, B., Simpson, W. (2003) "Corporate Governance, Board Diversity, and Firm Value,” Financial Review, 38, 33-53.

Charness, G. and U. Gneezy (2007) "Strong Evidence for Gender Differences in Investment," mimeo.

Charness, G. and M. Jackson (2007) "Group Play in Games and the Role of Consent in Network Formation,” Journal of Economic Theory, 136, 417-445.

Charness, G., L. Rigotti and A. Rustichini (2007) "Individual Behavior and Group Membership,” American Economic Review, 97, 1340-1352.

Croson, R. and N. Buchan (1999) "Gender and Culture: International Experimental Evidence from Trust Games,” American Economic Review P\&P, 89(2), 386-391.

Croson, R. and U. Gneezy (2009) “Gender Differences in Preferences," Journal of Economic Literature, 47(2), 1-27. 
Delfgaauw, J., Dur, R., Sol, J. and W. Verbeke (2009) "Tournament Incentives in The Field: Gender Differences in The Workplace” Tinbergen Institute Discussion Paper 09061/1.

Dufwenberg, M. and A. Murenb (2006) “Gender Composition in Teams,” Journal of Economic Behavior \& Organization, 61(1), 50-54.

Farrell, K., and P. Hersch (2005) "Additions to corporate boards: the effect of gender," Journal of Corporate Finance, 11, 85-106.

Gneezy, U., M. Niederle, and A. Rustichini (2003), "Performance in Competitive Environments: Gender Differences,” Quarterly Journal of Economics, 118(3), 10491074.

Manning, A. and Swaffield, J. (2008) “The Gender Gap in Early-Career Wage Growth”, The Economic Journal, 118 (July), 983-1024.

Miller, G. (2008) "Women's Suggrage, Political Responsiveness, and Child Survival in American History,” Quarterly Journal of Economics, 123(3), 1287-1327.

Niederle, M. and L. Vesterlund (2007) "Do Women Shy Away from Competition? Do Men Compete Too Much?” Quarterly Journal of Economics, 122, 1067-1101.

Sobel, J. (2006), “Information Aggregation and Group Decisions,” mimeo.

Stoner, J. A. F. (1968) "Risky and Cautious Shifts in Group Decisions: The Influence of Widely Held Values,” Journal of Experimental Social Psychology, 4, 442-459.

Zinovyeva, N., and M. Bagues (2010) “Does Gender Matter for Academic Promotion? Evidence from a randomized natural experiment”, mimeo. 
Figure 1a: Distributional Analysis forUG

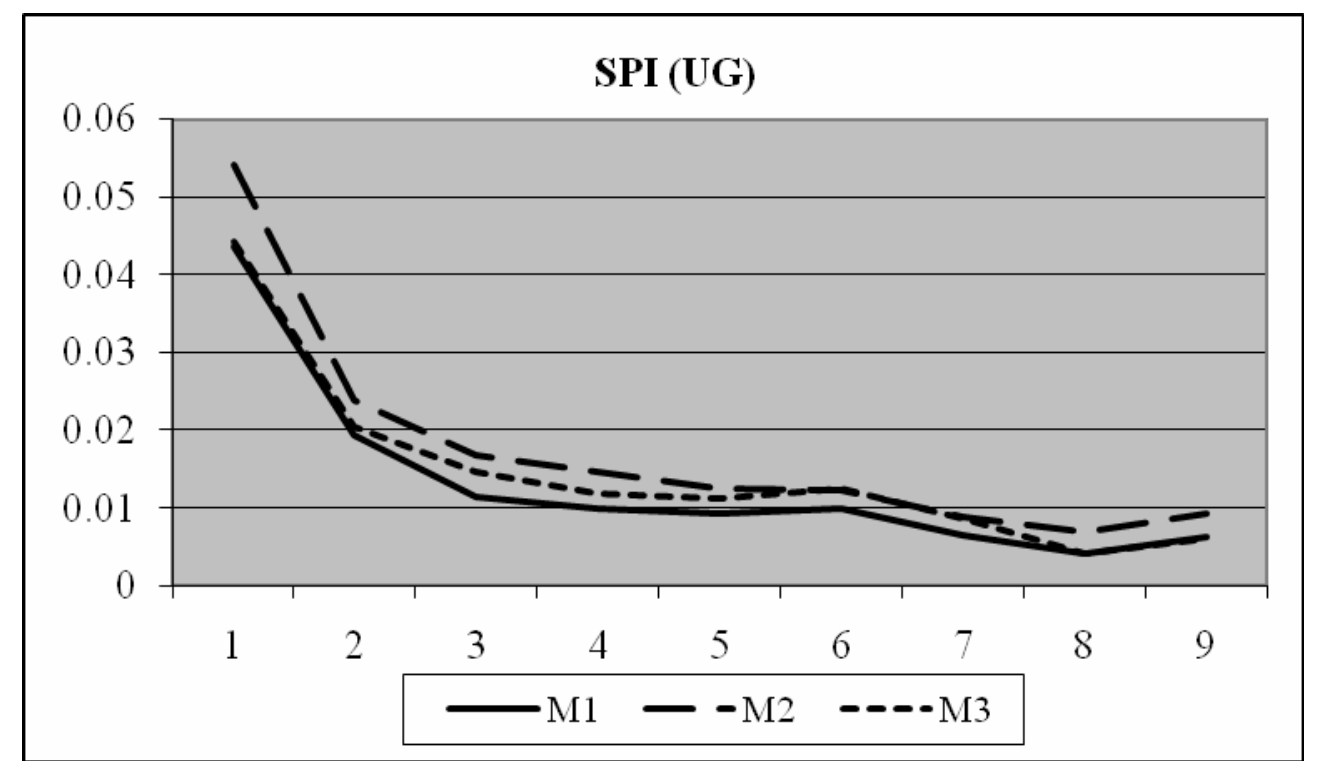

Figure 1b: Distributional Analysis for MBA

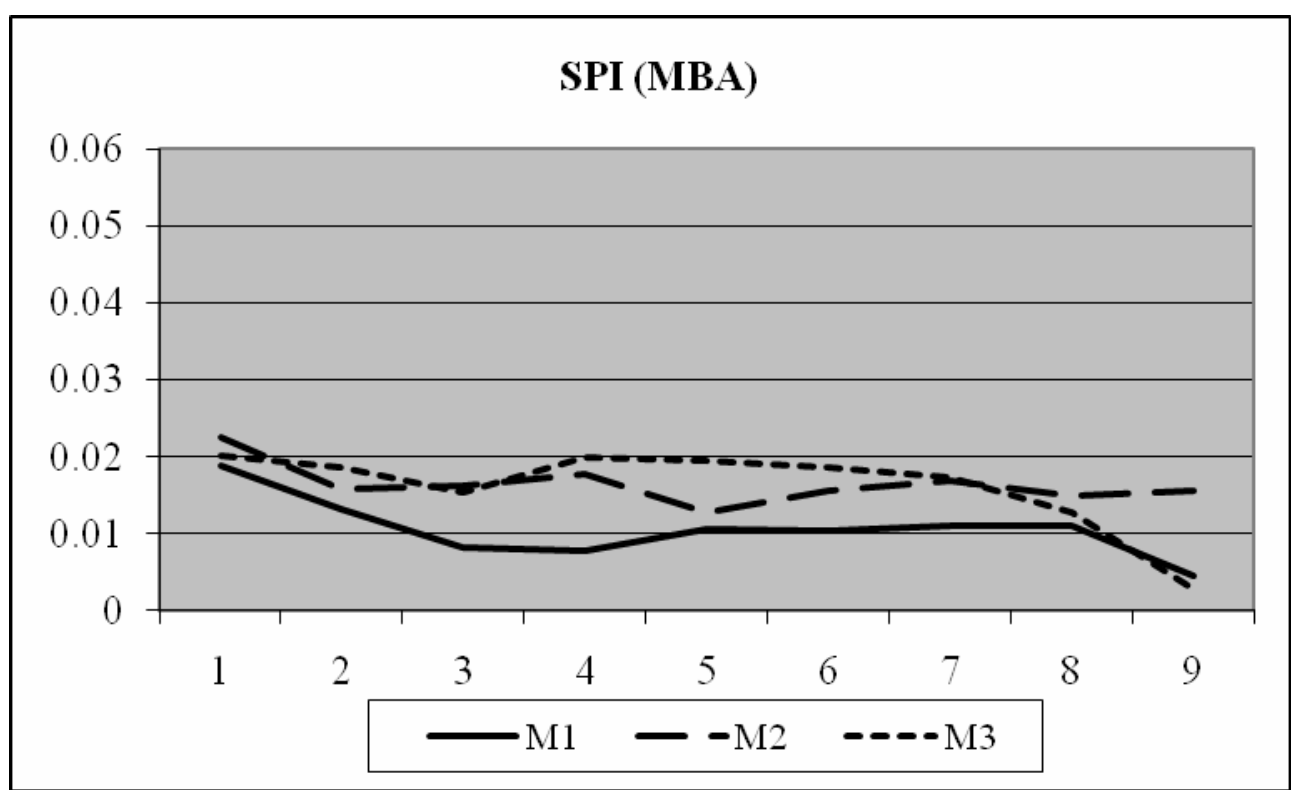

Notes: $10 \%$ to $90 \%$ quantile. Table 8 reports the same coefficients and includes the significance levels. All quantiles control for observable characteristics (as listed in Table 6), as well as controls for year and zone fixed effects. The standard errors in all columns are clustered at the year and zone level. The dependent variables, SPI, for all quantiles are standardized by subtracting the minimum SPI from the actual SPI and dividing this by the difference between the maximum and minimum SPI. The team gender categories, M1, M2 and M3, are all compared with the excluded category, M0. 
Table 1: Decisions and Outcomes

\begin{tabular}{c|c|c|c}
\hline \hline Area & Decisions & Midway Outcome & Final Outcome \\
\hline R\&D & Number of Formulas & R\&D Investment & \multirow{2}{*}{ SPI } \\
\hline Brand Management & $\begin{array}{c}\text { Price per Brand } \\
\text { Production per Brand }\end{array}$ & $\begin{array}{c}\text { Sales-Revenues-Costs- } \\
\text { Inventories-Profits }\end{array}$ & \\
\hline $\begin{array}{c}\text { Social and } \\
\text { Initianmental }\end{array}$ & $\begin{array}{c}\text { Social Sustainability actions } \\
\text { Environmental Sustainability } \\
\text { actions }\end{array}$ & $\begin{array}{c}\text { Social Sustainability Index (SSI) } \\
\text { Environmental Sustainability } \\
\text { Index (ESI) }\end{array}$ & \\
\hline \hline
\end{tabular}

Table 2: Explaining the SPI

\begin{tabular}{|c|c|c|c|c|c|c|c|c|c|c|}
\hline & \multicolumn{2}{|c|}{ SPI } & \multicolumn{2}{|c|}{ SPI } & \multicolumn{2}{|c|}{ SPI } & \multicolumn{2}{|c|}{ SPI } & \multicolumn{2}{|c|}{ SPI } \\
\hline & $\begin{array}{l}\text { UG } \\
(1)\end{array}$ & $\begin{array}{l}\text { MBA } \\
(2) \\
\end{array}$ & $\begin{array}{l}\text { UG } \\
(3)\end{array}$ & $\begin{array}{c}\text { MBA } \\
(4)\end{array}$ & $\begin{array}{l}\text { UG } \\
(5)\end{array}$ & $\begin{array}{l}\text { MBA } \\
(6) \\
\end{array}$ & $\begin{array}{l}\text { UG } \\
(7)\end{array}$ & $\begin{array}{c}\text { MBA } \\
(8)\end{array}$ & $\begin{array}{l}\text { UG } \\
(9)\end{array}$ & $\begin{array}{c}\text { MBA } \\
(10)\end{array}$ \\
\hline R\&D Inv. & $\begin{array}{c}3.40 \mathrm{e}-06 * * * \\
{[1.21 \mathrm{e}-06]}\end{array}$ & $\begin{array}{c}4.45 \mathrm{e}-06 * * * \\
{[1.31 \mathrm{e}-06]}\end{array}$ & $\begin{array}{c}.70 \mathrm{e}-06^{* *} \\
{[1.73 \mathrm{e}-06]}\end{array}$ & $\begin{array}{c}.67 \mathrm{e}-06^{* *} \\
{[1.83 \mathrm{e}-06]}\end{array}$ & & & & & & \\
\hline Profits & $\begin{array}{c}3.60 \mathrm{e}-06^{* * *} \\
{[2.21 \mathrm{e}-07]}\end{array}$ & $\begin{array}{c}2.71 \mathrm{e}-06^{* * *} \\
{[7.17 \mathrm{e}-07]}\end{array}$ & & & $\begin{array}{c}3.60 \mathrm{e}-06 * * * \\
{[2.02 \mathrm{e}-07]}\end{array}$ & $\begin{array}{c}2.76 \mathrm{e}-06^{* * *} \\
{[6.72 \mathrm{e}-07]}\end{array}$ & & & & \\
\hline SSI & $\begin{array}{l}0.119 * * \\
{[0.0454]}\end{array}$ & $\begin{array}{l}0.151^{* * *} \\
{[0.0498]}\end{array}$ & & & & & $\begin{array}{c}0,0121 \\
{[0.0570]}\end{array}$ & $\begin{array}{c}0,0623 \\
{[0.0757]}\end{array}$ & & \\
\hline ESI & $\begin{array}{c}0.182^{* * *} \\
{[0.0202]}\end{array}$ & $\begin{array}{c}0.181 * * * \\
{[0.0427]}\end{array}$ & & & & & & & $\begin{array}{c}0.229 * * * \\
{[0.0401]}\end{array}$ & $\begin{array}{c}0.240 * * * \\
{[0.0470]}\end{array}$ \\
\hline 2008 & $\begin{array}{c}117.6^{* * * *} \\
{[8.848]}\end{array}$ & $\begin{array}{c}83.94 * * * \\
{[29.00]}\end{array}$ & $\begin{array}{c}-21.67 * * * \\
{[5.251]}\end{array}$ & $\begin{array}{c}-21.20^{* * *} \\
{[7.414]}\end{array}$ & $\begin{array}{c}114.0^{* * * *} \\
{[8.854]}\end{array}$ & $\begin{array}{c}85.61^{* * *} \\
{[26.97]}\end{array}$ & $\begin{array}{c}-25.02 * * * \\
{[6.245]}\end{array}$ & $\begin{array}{c}-20.35^{* * * *} \\
{[6.555]}\end{array}$ & $\begin{array}{c}-23.62 * * * \\
{[6.197]}\end{array}$ & $\begin{array}{c}-20.91 * * * \\
{[6.716]}\end{array}$ \\
\hline 2009 & $\begin{array}{c}-12.17 * * * \\
{[3.621]}\end{array}$ & $\begin{array}{c}1,345 \\
{[11.67]}\end{array}$ & $\begin{array}{c}38.22 * * * \\
{[5.122]}\end{array}$ & $\begin{array}{c}44.93 * * * \\
{[6.960]}\end{array}$ & $\begin{array}{c}-2,398 \\
{[3.137]}\end{array}$ & $\begin{array}{c}11,94 \\
{[11.03]}\end{array}$ & $\begin{array}{c}47.12^{* * *} \\
{[4.115]}\end{array}$ & $\begin{array}{c}55.11 * * * \\
{[5.583]}\end{array}$ & $\begin{array}{c}44.84 * * * \\
{[4.310]}\end{array}$ & $\begin{array}{c}51.39 * * * \\
{[5.379]}\end{array}$ \\
\hline Constant & $\begin{array}{r}-146.8 * \\
{[80.91]} \\
\end{array}$ & $\begin{array}{c}21,34 \\
{[161.7]} \\
\end{array}$ & $\begin{array}{c}972.2 * * * \\
{[4.059]} \\
\end{array}$ & $\begin{array}{c}976.6^{* * *} \\
{[5.370]} \\
\end{array}$ & $\begin{array}{c}161.2 * * * \\
{[45.39]} \\
\end{array}$ & $\begin{array}{c}349.2 * * \\
{[152.0]} \\
\end{array}$ & $\begin{array}{c}958.3^{* * *} \\
{[57.71]} \\
\end{array}$ & $\begin{array}{c}911.3^{* * *} \\
{[77.86]} \\
\end{array}$ & $\begin{array}{c}729.3 * * * \\
{[42.25]} \\
\end{array}$ & $\begin{array}{c}721.6 * * * \\
{[49.56]} \\
\end{array}$ \\
\hline $\begin{array}{l}\text { Observations } \\
\text { R-squared }\end{array}$ & $\begin{array}{l}7531 \\
0.668\end{array}$ & $\begin{array}{l}2889 \\
0.523\end{array}$ & $\begin{array}{l}7650 \\
0.078\end{array}$ & $\begin{array}{l}2956 \\
0.094\end{array}$ & $\begin{array}{l}9098 \\
0.621\end{array}$ & $\begin{array}{l}3544 \\
0.488\end{array}$ & $\begin{array}{c}8956 \\
0.07\end{array}$ & $\begin{array}{l}3468 \\
0.084\end{array}$ & $\begin{array}{l}8956 \\
0.081\end{array}$ & $\begin{array}{l}3468 \\
0.098\end{array}$ \\
\hline
\end{tabular}

Notes: * denotes significance at the $10 \%$ level, ** denotes significance at the $5 \%$ and *** denotes significance at the $1 \%$ level. The standard errors in all columns are clustered at the year and zone level. 


\section{Table 3: Comparison of Top and Bottom Performing Teams’ Decision and Outcomes}

\begin{tabular}{|c|c|c|c|c|c|c|c|c|c|}
\hline \multicolumn{10}{|c|}{ Panel A: UNDERGRADUATES } \\
\hline & \multicolumn{3}{|c|}{2007} & \multicolumn{3}{|c|}{2008} & \multicolumn{3}{|c|}{2009} \\
\hline & $\begin{array}{c}\text { Top 10\% } \\
\text { Mean } \\
(1) \\
\end{array}$ & $\begin{array}{c}\text { Bottom } 10 \% \\
\text { Mean } \\
(2) \\
\end{array}$ & $\begin{array}{c}P \text {-Value } \\
\text { (3) } \\
\end{array}$ & $\begin{array}{l}\text { Top 10\% } \\
\text { Mean } \\
(4) \\
\end{array}$ & $\begin{array}{c}\text { Bottom 10\% } \\
\text { Mean } \\
(5) \\
\end{array}$ & $\begin{array}{c}P \text {-Value } \\
(6) \\
\end{array}$ & $\begin{array}{c}\text { Top 10\% } \\
\text { Mean } \\
(7) \\
\end{array}$ & $\begin{array}{c}\text { Bottom } 10 \% \\
\text { Mean } \\
(8) \\
\end{array}$ & $\begin{array}{c}P \text {-Value } \\
(9) \\
\end{array}$ \\
\hline SPI & 1113.53 & 809.69 & 0 & 1070.41 & 701.15 & 0 & 1113.82 & 777.53 & 0 \\
\hline No_formula & 1.55 & 1.51 & 0.36 & 1.56 & 1.38 & 0 & 1.58 & 1.59 & 0.83 \\
\hline R\&D Investment & 2316916 & 2030777 & 0.03 & 2614357 & 1604634 & 0 & 3855720 & 4099762 & 0.26 \\
\hline Price_Brand_1 & 7.13 & 6.45 & 0 & 7.71 & 6.79 & 0 & 13.02 & 13.25 & 0.16 \\
\hline Price_Brand_2 & 28.93 & 30.51 & 0 & 12.18 & 11.18 & 0 & 16.52 & 17.74 & 0 \\
\hline Prod_Brand_1 & 13800000 & 13200000 & 0 & 17000000 & 16400000 & 0.01 & 10800000 & 8954327 & 0 \\
\hline Prod_Brand_2 & 6988092 & 6013914 & 0 & 9556369 & 9864122 & 0.03 & 9975688 & 8133023 & 0 \\
\hline Sales & 20600000 & 18100000 & 0 & 26300000 & 23700000 & 0 & 20800000 & 15900000 & 0 \\
\hline Inventories & 167391 & 1107231 & 0 & 325418 & 2524436 & 0 & 0 & 1156228 & 0 \\
\hline Revenues & 297000000 & 246000000 & 0 & 243000000 & 197000000 & 0 & 304000000 & 237000000 & 0 \\
\hline Cost & 48300000 & 48300000 & 1 & 45300000 & 47300000 & 0 & 49100000 & 46600000 & 0 \\
\hline Profits & 248000000 & 197000000 & 0 & 197000000 & 150000000 & 0 & 255000000 & 190000000 & 0 \\
\hline SSI & 1026.45 & 1019 & 0 & 1016.57 & 1021.22 & 0.04 & 1023.33 & 1024.18 & 0.77 \\
\hline$\underline{\text { ESI }}$ & 1063.7 & 1050 & 0 & 1071.72 & 1044.81 & 0 & 1088.36 & 1057.51 & 0 \\
\hline \multicolumn{10}{|c|}{ Panel B: MBA } \\
\hline & \multicolumn{3}{|c|}{2007} & \multicolumn{3}{|c|}{2008} & \multicolumn{3}{|c|}{2009} \\
\hline & $\begin{array}{c}\text { Top 10\% } \\
\text { Mean } \\
(1) \\
\end{array}$ & $\begin{array}{c}\text { Bottom } 10 \% \\
\text { Mean } \\
(2) \\
\end{array}$ & $\begin{array}{c}P \text {-Value } \\
(3) \\
\end{array}$ & $\begin{array}{c}\text { Top 10\% } \\
\text { Mean } \\
(4) \\
\end{array}$ & $\begin{array}{c}\text { Bottom 10\% } \\
\text { Mean } \\
(5) \\
\end{array}$ & $\begin{array}{c}P \text {-Value } \\
(6) \\
\end{array}$ & $\begin{array}{c}\text { Top 10\% } \\
\text { Mean } \\
(7) \\
\end{array}$ & $\begin{array}{c}\text { Bottom } 10 \% \\
\text { Mean } \\
(8) \\
\end{array}$ & $\begin{array}{c}P \text {-Value } \\
(9) \\
\end{array}$ \\
\hline SPI & 1111.78 & 832.91 & 0 & 1075.61 & 726.08 & 0 & 1114.37 & 816.76 & 0 \\
\hline No_formula & 1.51 & 1.43 & 0.25 & 1.57 & 1.29 & 0 & 1.64 & 1.56 & 0.27 \\
\hline R\&D Investment & 2296266 & 2064151 & 0.27 & 2565672 & 1687500 & 0 & 4273469 & 4107857 & 0.62 \\
\hline Price_Brand_1 & 7.09 & 6.4 & 0 & 7.72 & 6.95 & 0 & 12.94 & 12.98 & 0.86 \\
\hline Price_Brand_2 & 28.86 & 30.15 & 0 & 12.13 & 11.24 & 0.07 & 16.47 & 17.84 & 0 \\
\hline Prod_Brand_1 & 13800000 & 13400000 & 0 & 17100000 & 16100000 & 0.01 & 10800000 & 9338049 & 0 \\
\hline Prod_Brand_2 & 6945655 & 6060997 & 0 & 9504046 & 10200000 & 0 & 10000000 & 8371768 & 0 \\
\hline Sales & 20600000 & 18700000 & 0 & 26400000 & 23900000 & 0 & 20800000 & 16900000 & 0 \\
\hline Inventories & 196821 & 681712 & 0 & 233945 & 2417731 & 0 & 0 & 808712 & 0 \\
\hline Revenues & 296000000 & 253000000 & 0 & 244000000 & 199000000 & 0 & 304000000 & 250000000 & 0 \\
\hline Cost & 48300000 & 48600000 & 0.32 & 45600000 & 47600000 & 0.03 & 48800000 & 48000000 & 0.04 \\
\hline Profits & 248000000 & 204000000 & 0 & 198000000 & 152000000 & 0 & 255000000 & 202000000 & 0 \\
\hline SSI & 1020.38 & 1017.99 & 0.45 & 1014.55 & 1016.7 & 0.52 & 1017.48 & 1024.48 & 0.13 \\
\hline ESI & 1061.89 & 1044.84 & 0 & 1080.37 & 1046.44 & 0 & 1107.48 & 1062.17 & 0 \\
\hline
\end{tabular}

Notes: In 2007, brand 1 is a low-income brand, while brand 2 is a high-income brand. In 2008, brand 1 is a low-income brand, while brand 2 is a brand directed to singles. In 2009, brand 1 is a brand directed to singles, while brand 2 is a medium-income brand. For further description see Section 5.2. The $p$-values for the one-way ANOVA test of equality of means across the average decisions and outcomes between the top and bottom 10\% teams are shown in columns (3), (6) and (9). 
Table 4-Demographics at the Individual Level

\begin{tabular}{|c|c|c|c|c|}
\hline & \multicolumn{2}{|c|}{ Undergraduates } & \multicolumn{2}{|c|}{ MBAs } \\
\hline & Women & Men & Women & Men \\
\hline Mean Age & $\begin{array}{l}22.111 \\
(2.068) \\
\end{array}$ & $\begin{array}{r}22.615 \\
(2.327) \\
\end{array}$ & $\begin{array}{r}26.175 \\
(3.551) \\
\end{array}$ & $\begin{array}{l}27.116 \\
(4.130) \\
\end{array}$ \\
\hline Business & $\begin{array}{c}0.530 \\
(0.499)\end{array}$ & $\begin{array}{c}0.482 \\
(0.500)\end{array}$ & $\begin{array}{c}0.780 \\
(0.414)\end{array}$ & $\begin{array}{c}0.772 \\
(0.419)\end{array}$ \\
\hline Economics & $\begin{array}{c}0.277 \\
(0.447)\end{array}$ & $\begin{array}{c}0.276 \\
(0.447)\end{array}$ & $\begin{array}{c}0.143 \\
(0.350)\end{array}$ & $\begin{array}{c}0.159 \\
(0.366)\end{array}$ \\
\hline Sciences & $\begin{array}{c}0.115 \\
(0.319)\end{array}$ & $\begin{array}{c}0.199 \\
(0.399)\end{array}$ & $\begin{array}{c}0.039 \\
(0.193)\end{array}$ & $\begin{array}{c}0.051 \\
(0.220)\end{array}$ \\
\hline Other Fields & $\begin{array}{c}0.079 \\
(0.269)\end{array}$ & $\begin{array}{c}0.043 \\
(0.202)\end{array}$ & $\begin{array}{c}0.038 \\
(0.192)\end{array}$ & $\begin{array}{c}0.018 \\
(0.132) \\
\end{array}$ \\
\hline Central Europe & $\begin{array}{c}0.077 \\
(0.266)\end{array}$ & $\begin{array}{c}0.103 \\
(0.305)\end{array}$ & $\begin{array}{c}0.134 \\
(0.341)\end{array}$ & $\begin{array}{c}0.140 \\
(0.347)\end{array}$ \\
\hline South Europe & $\begin{array}{c}0.061 \\
(0.239)\end{array}$ & $\begin{array}{c}0.086 \\
(0.280)\end{array}$ & $\begin{array}{c}0.091 \\
(0.287)\end{array}$ & $\begin{array}{c}0.092 \\
(0.289)\end{array}$ \\
\hline Eastern Europe & $\begin{array}{c}0.107 \\
(0.309)\end{array}$ & $\begin{array}{c}0.113 \\
(0.316)\end{array}$ & $\begin{array}{c}0.060 \\
(0.238)\end{array}$ & $\begin{array}{c}0.046 \\
(0.209)\end{array}$ \\
\hline Africa & $\begin{array}{c}0.072 \\
(0.258)\end{array}$ & $\begin{array}{c}0.102 \\
(0.303)\end{array}$ & $\begin{array}{c}0.059 \\
(0.235)\end{array}$ & $\begin{array}{c}0.061 \\
(0.239)\end{array}$ \\
\hline South America & $\begin{array}{c}0.049 \\
(0.216)\end{array}$ & $\begin{array}{c}0.072 \\
(0.259)\end{array}$ & $\begin{array}{c}0.049 \\
(0.217)\end{array}$ & $\begin{array}{c}0.061 \\
(0.239)\end{array}$ \\
\hline North America & $\begin{array}{c}0.039 \\
(0.194)\end{array}$ & $\begin{array}{c}0.038 \\
(0.191)\end{array}$ & $\begin{array}{c}0.181 \\
(0.385)\end{array}$ & $\begin{array}{c}0.118 \\
(0.322)\end{array}$ \\
\hline East Asia & $\begin{array}{c}0.430 \\
(0.495)\end{array}$ & $\begin{array}{c}0.300 \\
(0.458)\end{array}$ & $\begin{array}{c}0.218 \\
(0.413)\end{array}$ & $\begin{array}{c}0.141 \\
(0.348)\end{array}$ \\
\hline South Asia & $\begin{array}{c}0.162 \\
(0.368)\end{array}$ & $\begin{array}{c}0.183 \\
(0.386)\end{array}$ & $\begin{array}{c}0.202 \\
(0.402)\end{array}$ & $\begin{array}{c}0.338 \\
(0.473)\end{array}$ \\
\hline Area Others & $\begin{array}{c}0.003 \\
(0.055)\end{array}$ & $\begin{array}{c}0.003 \\
(0.052)\end{array}$ & $\begin{array}{c}0.005 \\
(0.067)\end{array}$ & $\begin{array}{c}0.004 \\
(0.062) \\
\end{array}$ \\
\hline Foreign at Institution & $\begin{array}{c}0.104 \\
(0.305)\end{array}$ & $\begin{array}{c}0.112 \\
(0.315)\end{array}$ & $\begin{array}{c}0.257 \\
(0.437)\end{array}$ & $\begin{array}{c}0.248 \\
(0.432) \\
\end{array}$ \\
\hline Number Individuals 2007 & 4,727 & 5,655 & 1,672 & 2,669 \\
\hline Number Individuals 2008 & 4,457 & 5,072 & 1,288 & 2,356 \\
\hline Number Individuals 2009 & 3,572 & 3,798 & 974 & 1,672 \\
\hline Total Number Individuals & 12,759 & 14,525 & 3,934 & 6,697 \\
\hline
\end{tabular}

Notes: Business, Economics, Sciences and Other Fields are dummy variables representing categories for the fields of study of the individuals. Each category takes a value of 1 if the field of study of the individual belongs to that category, and 0 otherwise. Table A.1 reports the classification of fields of study in the four categories. Geographical areas are dummy variables taking a value of 1 if the country of origin of the individual belongs to the respective geographical area, and 0 otherwise. Individuals not reporting a geographical area are collected in Area Others. Table A.2 reports the assignment of countries to the respective geographical areas. Foreign at Institution is a dummy variable giving a value of 1 when the country of origin of the individual does not coincide with the country where the educational institution is located, and a value of 0 otherwise. Standard errors are reported in brackets. 
Table 5-Demographics by Gender Composition of Teams

\begin{tabular}{|c|c|c|c|c|c|c|c|c|}
\hline & \multicolumn{4}{|c|}{ Undergraduates } & \multicolumn{4}{|c|}{ MBAs } \\
\hline & 3 Women & $\begin{array}{c}2 \text { Women } \\
-1 \text { Man } \\
\end{array}$ & $\begin{array}{c}1 \text { Woman } \\
-2 \text { Men } \\
\end{array}$ & 3 Men & 3 Women & $\begin{array}{c}2 \text { Women } \\
\text {-1 Man }\end{array}$ & $\begin{array}{l}1 \text { Woman } \\
-2 \text { Men } \\
\end{array}$ & 3 Men \\
\hline Mean Age & $\begin{array}{l}22.348 \\
(1.787)\end{array}$ & $\begin{array}{l}22.690 \\
(2.178) \\
\end{array}$ & $\begin{array}{l}22.922 \\
(2.059) \\
\end{array}$ & $\begin{array}{l}22.992 \\
(2.144)\end{array}$ & $\begin{array}{l}26.094 \\
(2.905) \\
\end{array}$ & $\begin{array}{l}26.916 \\
(3.115) \\
\end{array}$ & $\begin{array}{l}27.651 \\
(3.635) \\
\end{array}$ & $\begin{array}{l}27.385 \\
(3.753) \\
\end{array}$ \\
\hline Business (Team) & $\begin{array}{c}0.650 \\
(0.477)\end{array}$ & $\begin{array}{c}0.689 \\
(0.463)\end{array}$ & $\begin{array}{c}0.670 \\
(0.470)\end{array}$ & $\begin{array}{c}0.614 \\
(0.486)\end{array}$ & $\begin{array}{c}0.877 \\
(0.328)\end{array}$ & $\begin{array}{c}0.897 \\
(0.303)\end{array}$ & $\begin{array}{c}0.901 \\
(0.298)\end{array}$ & $\begin{array}{c}0.906 \\
(0.291)\end{array}$ \\
\hline Economics (Team) & $\begin{array}{c}0.422 \\
(0.494)\end{array}$ & $\begin{array}{c}0.442 \\
(0.496)\end{array}$ & $\begin{array}{c}0.407 \\
(0.491)\end{array}$ & $\begin{array}{c}0.419 \\
(0.493)\end{array}$ & $\begin{array}{c}0.279 \\
(0.449)\end{array}$ & $\begin{array}{c}0.270 \\
(0.444)\end{array}$ & $\begin{array}{c}0.299 \\
(0.458)\end{array}$ & $\begin{array}{c}0.292 \\
(0.455)\end{array}$ \\
\hline Sciences (Team) & $\begin{array}{c}0.138 \\
(0.345)\end{array}$ & $\begin{array}{c}0.224 \\
(0.417)\end{array}$ & $\begin{array}{c}0.291 \\
(0.454)\end{array}$ & $\begin{array}{c}0.285 \\
(0.451)\end{array}$ & $\begin{array}{c}0.062 \\
(0.242)\end{array}$ & $\begin{array}{c}0.091 \\
(0.288)\end{array}$ & $\begin{array}{c}0.096 \\
(0.295)\end{array}$ & $\begin{array}{c}0.089 \\
(0.285)\end{array}$ \\
\hline Other Fields (Team) & $\begin{array}{c}0.046 \\
(0.210)\end{array}$ & $\begin{array}{c}0.027 \\
(0.164)\end{array}$ & $\begin{array}{c}0.013 \\
(0.114)\end{array}$ & $\begin{array}{c}0.015 \\
(0.122)\end{array}$ & $\begin{array}{c}0.028 \\
(0.167)\end{array}$ & $\begin{array}{c}0.009 \\
(0.099)\end{array}$ & $\begin{array}{c}0.009 \\
(0.096)\end{array}$ & $\begin{array}{r}0.000 \\
(0.029)\end{array}$ \\
\hline $\begin{array}{l}\text { Central Europe } \\
\text { (Institution) }\end{array}$ & $\begin{array}{c}0.073 \\
(0.260)\end{array}$ & $\begin{array}{c}0.072 \\
(0.258)\end{array}$ & $\begin{array}{c}0.091 \\
(0.288)\end{array}$ & $\begin{array}{c}0.124 \\
(0.329)\end{array}$ & $\begin{array}{c}0.127 \\
(0.334)\end{array}$ & $\begin{array}{c}0.139 \\
(0.346)\end{array}$ & $\begin{array}{c}0.136 \\
(0.343)\end{array}$ & $\begin{array}{c}0.143 \\
(0.350)\end{array}$ \\
\hline $\begin{array}{l}\text { South Europe } \\
\text { (Institution) }\end{array}$ & $\begin{array}{c}0.052 \\
(0.223)\end{array}$ & $\begin{array}{c}0.060 \\
(0.238)\end{array}$ & $\begin{array}{c}0.077 \\
(0.266)\end{array}$ & $\begin{array}{c}0.101 \\
(0.302)\end{array}$ & $\begin{array}{c}0.091 \\
(0.288)\end{array}$ & $\begin{array}{c}0.087 \\
(0.283)\end{array}$ & $\begin{array}{c}0.094 \\
(0.292)\end{array}$ & $\begin{array}{c}0.091 \\
(0.287)\end{array}$ \\
\hline $\begin{array}{l}\text { Eastern Europe } \\
\text { (Institution) }\end{array}$ & $\begin{array}{c}0.110 \\
(0.313)\end{array}$ & $\begin{array}{c}0.105 \\
(0.307)\end{array}$ & $\begin{array}{c}0.103 \\
(0.305)\end{array}$ & $\begin{array}{c}0.122 \\
(0.328)\end{array}$ & $\begin{array}{c}0.073 \\
(0.260)\end{array}$ & $\begin{array}{c}0.058 \\
(0.234)\end{array}$ & $\begin{array}{c}0.048 \\
(0.215)\end{array}$ & $\begin{array}{c}0.040 \\
(0.197)\end{array}$ \\
\hline $\begin{array}{l}\text { Africa } \\
\text { (Institution) }\end{array}$ & $\begin{array}{c}0.063 \\
(0.244)\end{array}$ & $\begin{array}{c}0.067 \\
(0.251)\end{array}$ & $\begin{array}{c}0.093 \\
(0.291)\end{array}$ & $\begin{array}{c}0.121 \\
(0.327)\end{array}$ & $\begin{array}{c}0.062 \\
(0.242)\end{array}$ & $\begin{array}{c}0.049 \\
(0.216)\end{array}$ & $\begin{array}{c}0.065 \\
(0.248)\end{array}$ & $\begin{array}{c}0.059 \\
(0.235)\end{array}$ \\
\hline $\begin{array}{l}\text { South America } \\
\text { (Institution) }\end{array}$ & $\begin{array}{c}0.039 \\
(0.194)\end{array}$ & $\begin{array}{c}0.052 \\
(0.222)\end{array}$ & $\begin{array}{c}0.062 \\
(0.242)\end{array}$ & $\begin{array}{c}0.088 \\
(0.283)\end{array}$ & $\begin{array}{c}0.041 \\
(0.200)\end{array}$ & $\begin{array}{c}0.051 \\
(0.221)\end{array}$ & $\begin{array}{c}0.054 \\
(0.227)\end{array}$ & $\begin{array}{c}0.067 \\
(0.251)\end{array}$ \\
\hline $\begin{array}{l}\text { North America } \\
\text { (Institution) }\end{array}$ & $\begin{array}{c}0.038 \\
(0.191)\end{array}$ & $\begin{array}{c}0.037 \\
(0.189)\end{array}$ & $\begin{array}{c}0.044 \\
(0.205)\end{array}$ & $\begin{array}{c}0.033 \\
(0.179)\end{array}$ & $\begin{array}{c}0.258 \\
(0.438)\end{array}$ & $\begin{array}{c}0.163 \\
(0.369)\end{array}$ & $\begin{array}{c}0.126 \\
(0.332)\end{array}$ & $\begin{array}{c}0.101 \\
(0.301)\end{array}$ \\
\hline $\begin{array}{l}\text { East Asia } \\
\text { (Institution) }\end{array}$ & $\begin{array}{c}0.453 \\
(0.497)\end{array}$ & $\begin{array}{c}0.447 \\
(0.497)\end{array}$ & $\begin{array}{c}0.354 \\
(0.478)\end{array}$ & $\begin{array}{c}0.201 \\
(0.401)\end{array}$ & $\begin{array}{c}0.187 \\
(0.391)\end{array}$ & $\begin{array}{c}0.242 \\
(0.428)\end{array}$ & $\begin{array}{c}0.215 \\
(0.411)\end{array}$ & $\begin{array}{c}0.068 \\
(0.252)\end{array}$ \\
\hline $\begin{array}{l}\text { South Asia } \\
\text { (Institution) }\end{array}$ & $\begin{array}{c}0.165 \\
(0.371)\end{array}$ & $\begin{array}{c}0.154 \\
(0.361)\end{array}$ & $\begin{array}{c}0.168 \\
(0.374)\end{array}$ & $\begin{array}{c}0.203 \\
(0.402)\end{array}$ & $\begin{array}{c}0.154 \\
(0.361)\end{array}$ & $\begin{array}{c}0.201 \\
(0.401)\end{array}$ & $\begin{array}{c}0.252 \\
(0.434)\end{array}$ & $\begin{array}{c}0.425 \\
(0.494)\end{array}$ \\
\hline $\begin{array}{l}\text { Area Others } \\
\text { (Institution) }\end{array}$ & $\begin{array}{c}0.002 \\
(0.054)\end{array}$ & $\begin{array}{c}0.003 \\
(0.056)\end{array}$ & $\begin{array}{c}0.002 \\
(0.054)\end{array}$ & $\begin{array}{c}0.002 \\
(0.047)\end{array}$ & $\begin{array}{c}0.002 \\
(0.051)\end{array}$ & $\begin{array}{c}0.006 \\
(0.078)\end{array}$ & $\begin{array}{c}0.004 \\
(0.065)\end{array}$ & $\begin{array}{c}0.003 \\
(0.058)\end{array}$ \\
\hline Field Diversity & $\begin{array}{c}0.545 \\
(0.706)\end{array}$ & $\begin{array}{c}0.735 \\
(0.756)\end{array}$ & $\begin{array}{c}0.741 \\
(0.781)\end{array}$ & $\begin{array}{c}0.595 \\
(0.728)\end{array}$ & $\begin{array}{c}0.454 \\
(0.640)\end{array}$ & $\begin{array}{c}0.566 \\
(0.700)\end{array}$ & $\begin{array}{c}0.582 \\
(0.720)\end{array}$ & $\begin{array}{c}0.490 \\
(0.685)\end{array}$ \\
\hline Country Diversity & $\begin{array}{c}0.120 \\
(0.384)\end{array}$ & $\begin{array}{c}0.144 \\
(0.417)\end{array}$ & $\begin{array}{c}0.171 \\
(0.449)\end{array}$ & $\begin{array}{c}0.142 \\
(0.410)\end{array}$ & $\begin{array}{c}0.507 \\
(0.751)\end{array}$ & $\begin{array}{c}0.491 \\
(0.745)\end{array}$ & $\begin{array}{c}0 ., 470 \\
(0.728)\end{array}$ & $\begin{array}{c}0.376 \\
(0.684)\end{array}$ \\
\hline Institution Diversity & $\begin{array}{c}0.284 \\
(0.792) \\
\end{array}$ & $\begin{array}{c}0.322 \\
(0.824) \\
\end{array}$ & $\begin{array}{c}0.358 \\
(0.854) \\
\end{array}$ & $\begin{array}{c}0.341 \\
(0.845)\end{array}$ & $\begin{array}{c}0.762 \\
(1.130) \\
\end{array}$ & $\begin{array}{c}0.803 \\
(1.174) \\
\end{array}$ & $\begin{array}{c}0.775 \\
(1.159) \\
\end{array}$ & $\begin{array}{c}0.732 \\
(1.158) \\
\end{array}$ \\
\hline Number Teams 2007 & 623 & 913 & 1,032 & 893 & 167 & 335 & 501 & 444 \\
\hline Number Teams 2008 & 600 & 867 & 923 & 787 & 119 & 277 & 377 & 442 \\
\hline Number Teams 2009 & 484 & 692 & 739 & 543 & 97 & 197 & 289 & 299 \\
\hline Total Number of Teams & 1,707 & 2,472 & 2,694 & 2,223 & 383 & 809 & 1,167 & 1,185 \\
\hline
\end{tabular}

Notes: Business (Team), Economics (Team), Sciences (Team) and Other Fields (Team) are dummy variables representing categories for the fields of study of the individuals in the team. A given category takes a value of 1 if the field of study of any of the three individuals of the team belongs to that category and 0 otherwise. Table A.1 reports the classification of fields of study in the four categories. Geographical areas are dummy variables taking a value of 1 if the country where the institution is located belongs to the respective geographical area, and 0 otherwise. Institutions that are unclassified geographically are collected in Area Others (Institution). Table A.2 reports the assignment of countries to the geographical areas. Field Diversity takes a value of 0 , of 1 , or of 2 if the maximum number of team members with fields of study belonging to the same category is 3 , 2, or 1, respectively. Country Diversity takes a value of 0 , of 1 , or of 2 if the maximum number of team members with the same country of origin is 3,2 , or 1 , respectively. Institution Diversity takes a value of 0 , of 1 , of 2 , or of 3 , if the number of team members originally from a country different to the country of the institution is $0,1,2$, or 3, respectively. Standard errors are reported in brackets. 
Table 6: Gender Composition of Teams on SPI

\begin{tabular}{|c|c|c|c|c|}
\hline & \multicolumn{2}{|c|}{ Stand. SPI } & \multicolumn{2}{|c|}{ Stand. SPI } \\
\hline & $\begin{array}{l}\text { UG } \\
(1)\end{array}$ & $\begin{array}{c}\text { MBA } \\
(2)\end{array}$ & $\begin{array}{l}\text { UG } \\
(3)\end{array}$ & $\begin{array}{c}\text { MBA } \\
\text { (4) }\end{array}$ \\
\hline \multirow[t]{2}{*}{ M1 } & $0.0167 * * *$ & $0.0247^{*}$ & $0.0174 * *$ & 0.0154 \\
\hline & {$[0.00560]$} & {$[0.0132]$} & {$[0.00638]$} & [0.00924] \\
\hline \multirow[t]{2}{*}{ M2 } & $0.0190 * * *$ & $0.0323^{*}$ & $0.0232 * * *$ & $0.0249 * * *$ \\
\hline & {$[0.00437]$} & {$[0.0170]$} & {$[0.00558]$} & [0.00803] \\
\hline \multirow[t]{2}{*}{ M3 } & 0.0103 & $0.0452 *$ & $0.0195^{* * *}$ & $0.0219 * * *$ \\
\hline & {$[0.0105]$} & {$[0.0255]$} & {$[0.00358]$} & [0.00759] \\
\hline \multirow[t]{2}{*}{ Central Europe } & & & 0.0017 & -0.00661 \\
\hline & & & {$[0.00757]$} & [0.00944] \\
\hline \multirow[t]{2}{*}{ South Europe } & & & -0.00972 & $-0.0174^{*}$ \\
\hline & & & {$[0.0108]$} & {$[0.0101]$} \\
\hline \multirow[t]{2}{*}{ Eastern Europe } & & & $0.0184^{* *}$ & \\
\hline & & & {$[0.00759]$} & \\
\hline \multirow[t]{2}{*}{ Africa } & & & -0.0176 & $-0.0209 *$ \\
\hline & & & [0.0123] & [0.0105] \\
\hline \multirow[t]{2}{*}{ South America } & & & 0.00292 & -0.00587 \\
\hline & & & {$[0.00717]$} & [0.0157] \\
\hline \multirow[t]{2}{*}{ North America } & & & & -0.00831 \\
\hline & & & & {$[0.00675]$} \\
\hline \multirow[t]{2}{*}{ East Asia } & & & 0.0103 & -0.00142 \\
\hline & & & {$[0.00745]$} & {$[0.00961]$} \\
\hline \multirow[t]{2}{*}{ South Asia } & & & $0.0147 * *$ & 0.00495 \\
\hline & & & {$[0.00681]$} & [0.00839] \\
\hline \multirow[t]{2}{*}{ Area Others } & & & -0.0109 & 0.00482 \\
\hline & & & [0.0139] & {$[0.00722]$} \\
\hline \multirow[t]{2}{*}{ Mean Age } & & & $1.43 \mathrm{E}-06$ & $0.00270 * * *$ \\
\hline & & & {$[0.00106]$} & [0.000711] \\
\hline \multirow[t]{2}{*}{2008} & & & $0.110^{* * *}$ & $0.262 * * *$ \\
\hline & & & {$[0.00447]$} & {$[0.00572]$} \\
\hline \multirow[t]{2}{*}{2009} & & & $0.153^{* * *}$ & $0.270 * * *$ \\
\hline & & & [0.00469] & {$[0.00866]$} \\
\hline \multirow[t]{2}{*}{ Institution Diversity } & & & $0.00402 * *$ & 0.00188 \\
\hline & & & {$[0.00195]$} & [0.00284] \\
\hline \multirow[t]{2}{*}{ Nationality Diversity } & & & -0.00098 & 0.00136 \\
\hline & & & {$[0.00271]$} & [0.00413] \\
\hline \multirow[t]{2}{*}{ Field Diversity } & & & 0.00117 & -0.00465 \\
\hline & & & {$[0.00186]$} & {$[0.00506]$} \\
\hline \multirow[t]{2}{*}{ Economics (Team) } & & & 0.000193 & 0.0012 \\
\hline & & & {$[0.00497]$} & {$[0.00772]$} \\
\hline \multirow[t]{2}{*}{ Science (Team) } & & & -0.00546 & $-0.0184^{*}$ \\
\hline & & & {$[0.00484]$} & [0.00982] \\
\hline Business (Team) & & & -0.00423 & -0.00871 \\
\hline & & & {$[0.00316]$} & [0.0107] \\
\hline Others (Team) & & & $-0.0103^{* *}$ & $-0.0558 * *$ \\
\hline & & & [0.00499] & {$[0.0208]$} \\
\hline Constant & $0.739 * * *$ & $0.684 * * *$ & $0.652 * * *$ & $0.481 * * *$ \\
\hline & {$[0.0185]$} & {$[0.0335]$} & [0.0259] & {$[0.0221]$} \\
\hline Observations & 9098 & 3544 & 8997 & 3481 \\
\hline
\end{tabular}

Notes: * denotes significance at the $10 \%$ level, ** denotes significance at the $5 \%$ and $* * *$ denotes significance at the $1 \%$ level. The standard errors in all columns are clustered at the year and zone level. The dependent variable, SPI, is standardized by subtracting the minimum SPI from the SPI and dividing this by the difference between the maximum and minimum SPI. The excluded team gender category is M0 (i.e., all women teams). 
Table 7: Gender Composition of Teams on SPI: Robustness

\begin{tabular}{lcccccc}
\hline & \multicolumn{2}{c}{ Stand. SPI } & \multicolumn{2}{c}{ Stand. SPI } & \multicolumn{2}{c}{ Stand. SPI } \\
& \multicolumn{2}{c}{ Additional Controls } & \multicolumn{2}{c}{ Add Rank } & \multicolumn{2}{c}{ School FE } \\
& UG & MBA & UG & MBA & UG & MBA \\
& $(1)$ & $(2)$ & $(3)$ & $(4)$ & $(5)$ & $(6)$ \\
\hline M1 & $0.0172^{* *}$ & $0.0155^{*}$ & $0.0157^{* *}$ & $0.0188^{*}$ & $0.0166^{* * *}$ & $0.0138^{*}$ \\
& {$[0.00643]$} & {$[0.00896]$} & {$[0.00606]$} & {$[0.0106]$} & {$[0.00347]$} & {$[0.00777]$} \\
M2 & $0.0224^{* * *}$ & $0.0252^{* * *}$ & $0.0236^{* * *}$ & $0.0252^{* * *}$ & $0.0220^{* * *}$ & $0.0210^{* * *}$ \\
& {$[0.00553]$} & {$[0.00779]$} & {$[0.00550]$} & {$[0.00856]$} & {$[0.00348]$} & {$[0.00758]$} \\
M3 & $0.0194^{* * *}$ & $0.0222^{* * *}$ & $0.0180^{* * *}$ & $0.0208^{* *}$ & $0.0201^{* * *}$ & $0.0204^{* * *}$ \\
& {$[0.00348]$} & {$[0.00741]$} & {$[0.00394]$} & {$[0.00884]$} & {$[0.00366]$} & {$[0.00776]$} \\
School Rank & & & $1.39 E-06$ & $-3.29 E-07$ & & \\
& & & {$[1.07 \mathrm{e}-06]$} & {$[1.26 \mathrm{e}-06]$} & & $0.653^{* * *}$ \\
Constant & $0.642^{* * *}$ & $0.426^{* * *}$ & $0.658^{* * *}$ & $0.465^{* * *}$ & $0.506^{* * *}$ \\
& {$[0.0288]$} & {$[0.0375]$} & {$[0.0274]$} & {$[0.0223]$} & {$[0.0234]$} & {$[0.0336]$} \\
Controls & Yes & Yes & Yes & Yes & Yes & Yes \\
Year FE & Yes & Yes & Yes & Yes & Yes & Yes \\
Zone FE & Yes & Yes & Yes & Yes & Yes & Yes \\
\hline Obs. & 8997 & 3481 & 7535 & 2435 & 8997 & 3481 \\
\hline \hline
\end{tabular}

Notes:* denotes significance at the $10 \%$ level, ** denotes significance at the $5 \%$ and $* * *$ denotes significance at the $1 \%$ level. The standard errors in all columns are clustered at the year and zone level. The dependent variable, SPI, is standardized by subtracting the minimum SPI from the SPI and dividing this by the difference between the maximum and minimum SPI. The excluded team gender category is M0 (i.e., all women teams). 
Table 8: Gender Composition of Teams on SPI: Distributional Analysis

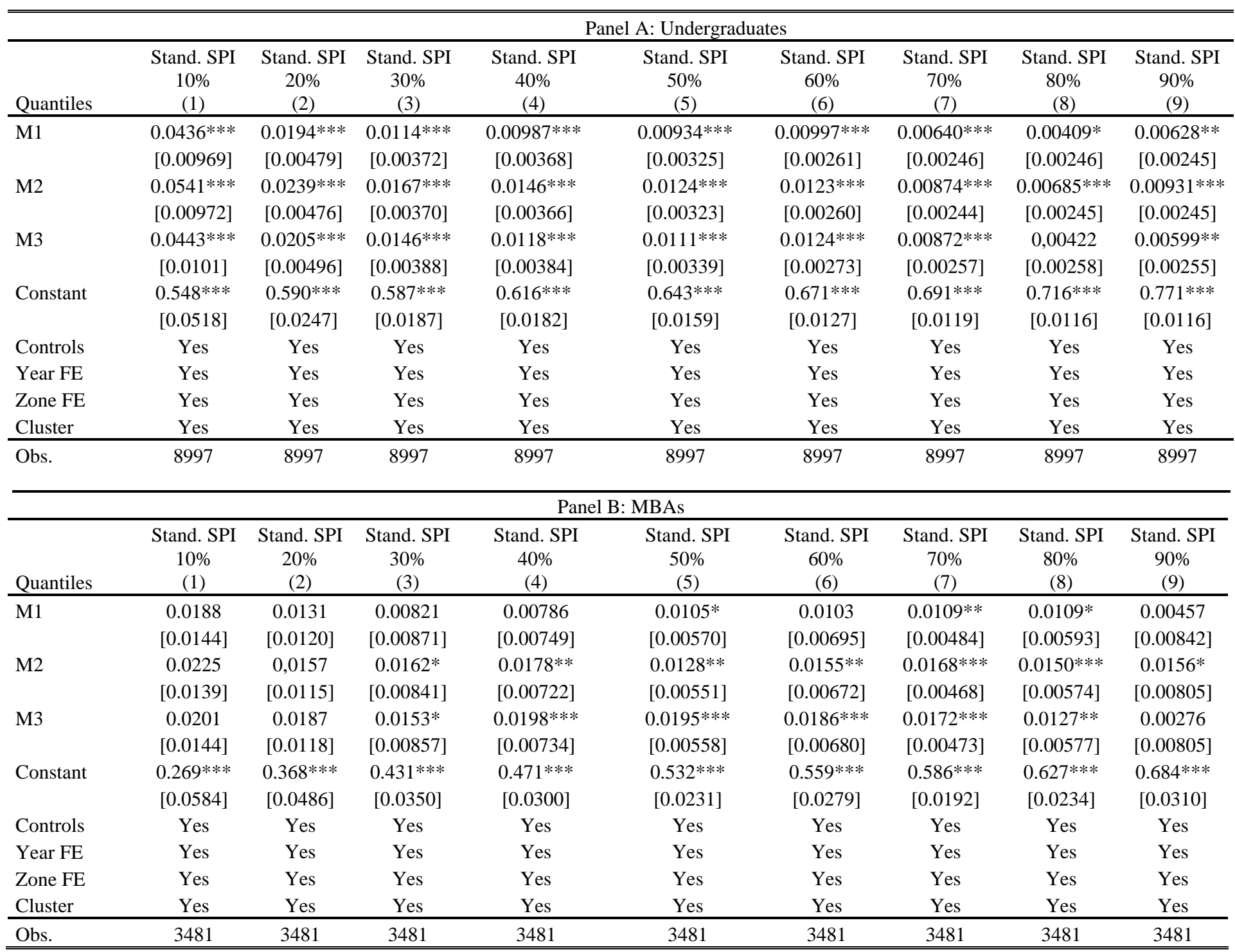

Notes:* denotes significance at the $10 \%$ level, ** denotes significance at the $5 \%$ and $* * *$ denotes significance at the $1 \%$ level. The standard errors in all columns are clustered at the year and zone level. The dependent variable, SPI, is standardized by subtracting the minimum SPI from the SPI and dividing this by the difference between the maximum and minimum SPI. The excluded team gender category is M0 (i.e., all women teams). This table corresponds to Figures 1a and 1b. 
Table 9: Gender Composition of Teams on R\&D decisions

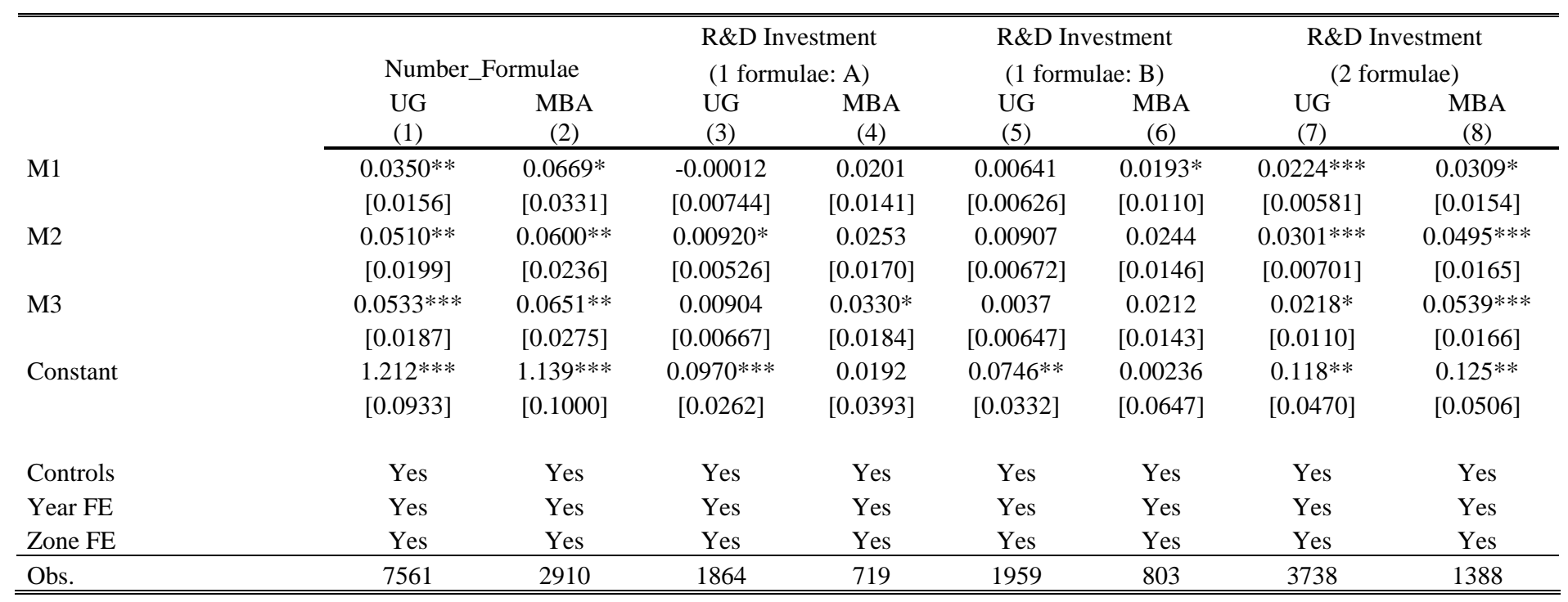

Notes:* denotes significance at the $10 \%$ level, ** denotes significance at the $5 \%$ and *** denotes significance at the $1 \%$ level. The standard errors in all columns are clustered at the year and zone level. The dependent variable, R\&D Investment in columns (3) to (8), is standardized by subtracting the minimum R\&D Investment from the R\&D Investment and dividing this by the difference between the maximum and minimum R\&D Investment. The excluded team gender category is M0 (i.e., all women teams). 
Table 10: Gender Composition of Teams on Brand Management

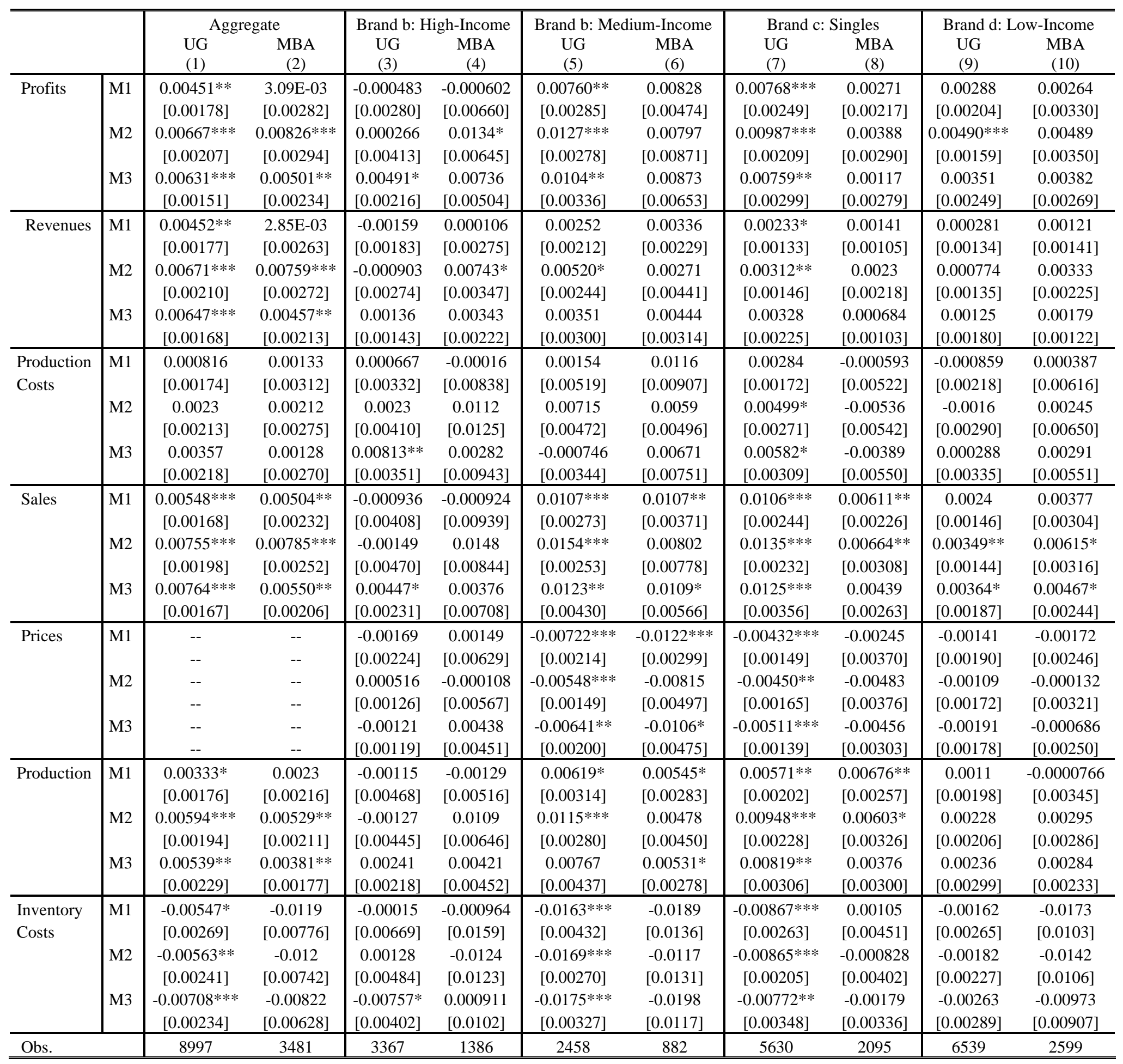

Notes:* denotes significance at the $10 \%$ level, ** denotes significance at the $5 \%$ and *** denotes significance at the $1 \%$ level. All columns control for observable characteristics (as listed in Table 6), as well as controls for year and zone fixed effects. The standard errors in all columns are clustered at the year and zone level. The dependent variables in all columns are standardized by subtracting the minimum value from the actual value and dividing this by the difference between the maximum and minimum value. The excluded team gender category is M0 (i.e., all women teams). 
Table 11: Gender Composition of Teams on Corporate Responsibility

\begin{tabular}{|c|c|c|c|c|}
\hline & \multicolumn{2}{|c|}{ Stand. SSI } & \multicolumn{2}{|c|}{ Stand. ESI } \\
\hline & $\begin{array}{l}\text { UG } \\
(1)\end{array}$ & $\begin{array}{c}\text { MBA } \\
(2) \\
\end{array}$ & $\begin{array}{l}\text { UG } \\
(3)\end{array}$ & $\begin{array}{c}\text { MBA } \\
(4)\end{array}$ \\
\hline M1 & $\begin{array}{c}-0.0140 * * \\
{[0.00674]}\end{array}$ & $\begin{array}{c}-0.0189 * \\
{[0.00956]}\end{array}$ & $\begin{array}{c}0.00387 \\
{[0.00520]}\end{array}$ & $\begin{array}{c}-0.00412 \\
{[0.0229]}\end{array}$ \\
\hline M2 & $\begin{array}{c}-0.0249 * * * \\
{[0.00697]}\end{array}$ & $\begin{array}{c}-0.0149 \\
{[0.0113]}\end{array}$ & $\begin{array}{c}0.00595 \\
{[0.00630]}\end{array}$ & $\begin{array}{c}0.00419 \\
{[0.0159]}\end{array}$ \\
\hline M3 & $\begin{array}{c}-0.0175^{* *} \\
{[0.00771]}\end{array}$ & $\begin{array}{c}-0.0324 * * * \\
{[0.0102]}\end{array}$ & $\begin{array}{c}-0.00332 \\
{[0.00669]}\end{array}$ & $\begin{array}{r}-0.00572 \\
{[0.0173]}\end{array}$ \\
\hline Constant & $\begin{array}{c}0.232 * * * \\
{[0.0366]}\end{array}$ & $\begin{array}{c}0.292 * * * \\
{[0.0442]}\end{array}$ & $\begin{array}{c}0.300^{* * *} \\
{[0.0437]}\end{array}$ & $\begin{array}{c}0.278 * * * \\
{[0.0627]}\end{array}$ \\
\hline Controls & Yes & Yes & Yes & Yes \\
\hline Year FE & Yes & Yes & Yes & Yes \\
\hline Zone FE & Yes & Yes & Yes & Yes \\
\hline Cluster & Yes & Yes & Yes & Yes \\
\hline Obs. & 8855 & 3405 & 8855 & 3405 \\
\hline
\end{tabular}

Notes:* denotes significance at the $10 \%$ level, ** denotes significance at the $5 \%$ and $* * *$ denotes significance at the 1\% level. The standard errors in all columns are clustered at the year and zone level. The dependent variables in all columns are standardized by subtracting the minimum value from the actual value and dividing this by the difference between the maximum and minimum value. The excluded team gender category is M0 (i.e., all women teams). 


\section{Table 12-Demographics by Individuals conditioning on the Gender Composition of Teams.}

\section{Panel A: Undergraduates}

\begin{tabular}{|c|c|c|c|c|c|c|}
\hline \multirow[b]{3}{*}{ Mean Age } & \multicolumn{3}{|c|}{ "Women in Teams Composed by: } & \multicolumn{3}{|c|}{ "Men in Teams Composed by: } \\
\hline & $\begin{array}{c}3 \\
\text { Women } \\
\end{array}$ & $\begin{array}{l}2 \text { Women-1 } \\
\text { Man }\end{array}$ & $\begin{array}{c}1 \text { Woman-2 } \\
\text { Men }\end{array}$ & 3 Men & $\begin{array}{l}2 \text { Men-1 } \\
\text { Woman }\end{array}$ & $\begin{array}{l}1 \text { Man-2 } \\
\text { Women }\end{array}$ \\
\hline & $\begin{array}{l}21.968 \\
(1.846)\end{array}$ & $\begin{array}{l}22.181 \\
(2.256) \\
\end{array}$ & $\begin{array}{l}22.264 \\
(2.100)\end{array}$ & $\begin{array}{l}22.578 \\
(2.318) \\
\end{array}$ & $\begin{array}{l}22.672 \\
(2.313)\end{array}$ & $\begin{array}{l}22.591 \\
(2.377)\end{array}$ \\
\hline Business & $\begin{array}{c}0.528 \\
(0.499)\end{array}$ & $\begin{array}{c}0.534 \\
(0.499)\end{array}$ & $\begin{array}{c}0.526 \\
(0.499)\end{array}$ & $\begin{array}{c}0.469 \\
(0.499)\end{array}$ & $\begin{array}{c}0.496 \\
(0.500)\end{array}$ & $\begin{array}{c}0.485 \\
(0.500)\end{array}$ \\
\hline Economics & $\begin{array}{c}0.299 \\
(0.458)\end{array}$ & $\begin{array}{c}0.268 \\
(0.443)\end{array}$ & $\begin{array}{c}0.249 \\
(0.432)\end{array}$ & $\begin{array}{c}0.285 \\
(0.452)\end{array}$ & $\begin{array}{c}0.259 \\
(0.438)\end{array}$ & $\begin{array}{c}0.291 \\
(0.455)\end{array}$ \\
\hline Sciences & $\begin{array}{c}0.093 \\
(0.291)\end{array}$ & $\begin{array}{c}0.117 \\
(0.322)\end{array}$ & $\begin{array}{c}0.152 \\
(0.359)\end{array}$ & $\begin{array}{c}0.207 \\
(0.405)\end{array}$ & $\begin{array}{c}0.202 \\
(0.401)\end{array}$ & $\begin{array}{c}0.171 \\
(0.377)\end{array}$ \\
\hline Other Fields & $\begin{array}{c}0.080 \\
(0.271)\end{array}$ & $\begin{array}{c}0.080 \\
(0.272) \\
\end{array}$ & $\begin{array}{c}0.074 \\
(0.261) \\
\end{array}$ & $\begin{array}{c}0.038 \\
(0.192) \\
\end{array}$ & $\begin{array}{c}0.043 \\
(0.204)\end{array}$ & $\begin{array}{c}0.052 \\
(0.223)\end{array}$ \\
\hline Central Europe & $\begin{array}{c}0.073 \\
(0.261)\end{array}$ & $\begin{array}{c}0.072 \\
(0.259)\end{array}$ & $\begin{array}{c}0.092 \\
(0.289)\end{array}$ & $\begin{array}{c}0.124 \\
(0.330)\end{array}$ & $\begin{array}{c}0.092 \\
(0.289)\end{array}$ & $\begin{array}{c}0.072 \\
(0.258)\end{array}$ \\
\hline South Europe & $\begin{array}{c}0.053 \\
(0.223)\end{array}$ & $\begin{array}{c}0.060 \\
(0.238)\end{array}$ & $\begin{array}{c}0.077 \\
(0.267)\end{array}$ & $\begin{array}{c}0.102 \\
(0.302)\end{array}$ & $\begin{array}{c}0.077 \\
(0.266)\end{array}$ & $\begin{array}{c}0.061 \\
(0.240)\end{array}$ \\
\hline East Europe & $\begin{array}{c}0.111 \\
(0.314)\end{array}$ & $\begin{array}{c}0.105 \\
(0.307)\end{array}$ & $\begin{array}{c}0.104 \\
(0.305)\end{array}$ & $\begin{array}{c}0.122 \\
(0.328)\end{array}$ & $\begin{array}{c}0.104 \\
(0.305)\end{array}$ & $\begin{array}{c}0.105 \\
(0.307)\end{array}$ \\
\hline Africa & $\begin{array}{c}0.065 \\
(0.246)\end{array}$ & $\begin{array}{c}0.068 \\
(0.251)\end{array}$ & $\begin{array}{c}0.094 \\
(0.291)\end{array}$ & $\begin{array}{c}0.122 \\
(0.327)\end{array}$ & $\begin{array}{c}0.094 \\
(0.291)\end{array}$ & $\begin{array}{c}0.068 \\
(0.251)\end{array}$ \\
\hline South America & $\begin{array}{c}0.039 \\
(0.194)\end{array}$ & $\begin{array}{c}0.052 \\
(0.222)\end{array}$ & $\begin{array}{c}0.063 \\
(0.243)\end{array}$ & $\begin{array}{c}0.088 \\
(0.283)\end{array}$ & $\begin{array}{c}0.063 \\
(0.242)\end{array}$ & $\begin{array}{c}0.052 \\
(0.223)\end{array}$ \\
\hline North America & $\begin{array}{c}0.038 \\
(0.191)\end{array}$ & $\begin{array}{c}0.038 \\
(0.190)\end{array}$ & $\begin{array}{c}0.044 \\
(0.205)\end{array}$ & $\begin{array}{c}0.033 \\
(0.180)\end{array}$ & $\begin{array}{c}0.044 \\
(0.205)\end{array}$ & $\begin{array}{c}0.038 \\
(0.190)\end{array}$ \\
\hline East Asia & $\begin{array}{c}0.453 \\
(0.498)\end{array}$ & $\begin{array}{c}0.447 \\
(0.497)\end{array}$ & $\begin{array}{c}0.355 \\
(0.479)\end{array}$ & $\begin{array}{c}0.202 \\
(0.402)\end{array}$ & $\begin{array}{c}0.355 \\
(0.479)\end{array}$ & $\begin{array}{c}0.447 \\
(0.497)\end{array}$ \\
\hline South Asia & $\begin{array}{c}0.165 \\
(0.372)\end{array}$ & $\begin{array}{c}0.154 \\
(0.361)\end{array}$ & $\begin{array}{c}0.169 \\
(0.374)\end{array}$ & $\begin{array}{c}0.204 \\
(0.403)\end{array}$ & $\begin{array}{c}0.169 \\
(0.375)\end{array}$ & $\begin{array}{c}0.154 \\
(0.361)\end{array}$ \\
\hline Area Others & $\begin{array}{c}0.003 \\
(0.054)\end{array}$ & $\begin{array}{c}0.003 \\
(0.057) \\
\end{array}$ & $\begin{array}{c}0.003 \\
(0.054) \\
\end{array}$ & $\begin{array}{c}0.002 \\
(0.047) \\
\end{array}$ & $\begin{array}{c}0.003 \\
(0.054)\end{array}$ & $\begin{array}{c}0.003 \\
(0.057)\end{array}$ \\
\hline Foreign at Institution & $\begin{array}{c}0.093 \\
(0.291)\end{array}$ & $\begin{array}{c}0.107 \\
(0.309) \\
\end{array}$ & $\begin{array}{c}0.120 \\
(0.325)\end{array}$ & $\begin{array}{c}0.111 \\
(0.315)\end{array}$ & $\begin{array}{c}0.116 \\
(0.320)\end{array}$ & $\begin{array}{c}0.104 \\
(0.305)\end{array}$ \\
\hline $\begin{array}{l}\text { Number Individuals Ed. } \\
2007 \\
\text { Number Individuals Ed. }\end{array}$ & 1,869 & 1,826 & 1,032 & 2,678 & 2,064 & 913 \\
\hline $\begin{array}{l}2008 \\
\text { Number Individuals Ed. }\end{array}$ & 1,800 & 1,734 & 923 & 2,360 & 1,846 & 866 \\
\hline $\begin{array}{l}2009 \\
\text { Total Number Individuals }\end{array}$ & $\begin{array}{l}1,453 \\
5,122\end{array}$ & $\begin{array}{l}1,384 \\
4,944\end{array}$ & $\begin{array}{c}738 \\
2,693\end{array}$ & $\begin{array}{l}1,629 \\
6,667\end{array}$ & $\begin{array}{l}1,478 \\
5,388\end{array}$ & $\begin{array}{c}691 \\
2,470\end{array}$ \\
\hline
\end{tabular}


Panel B: MBAs

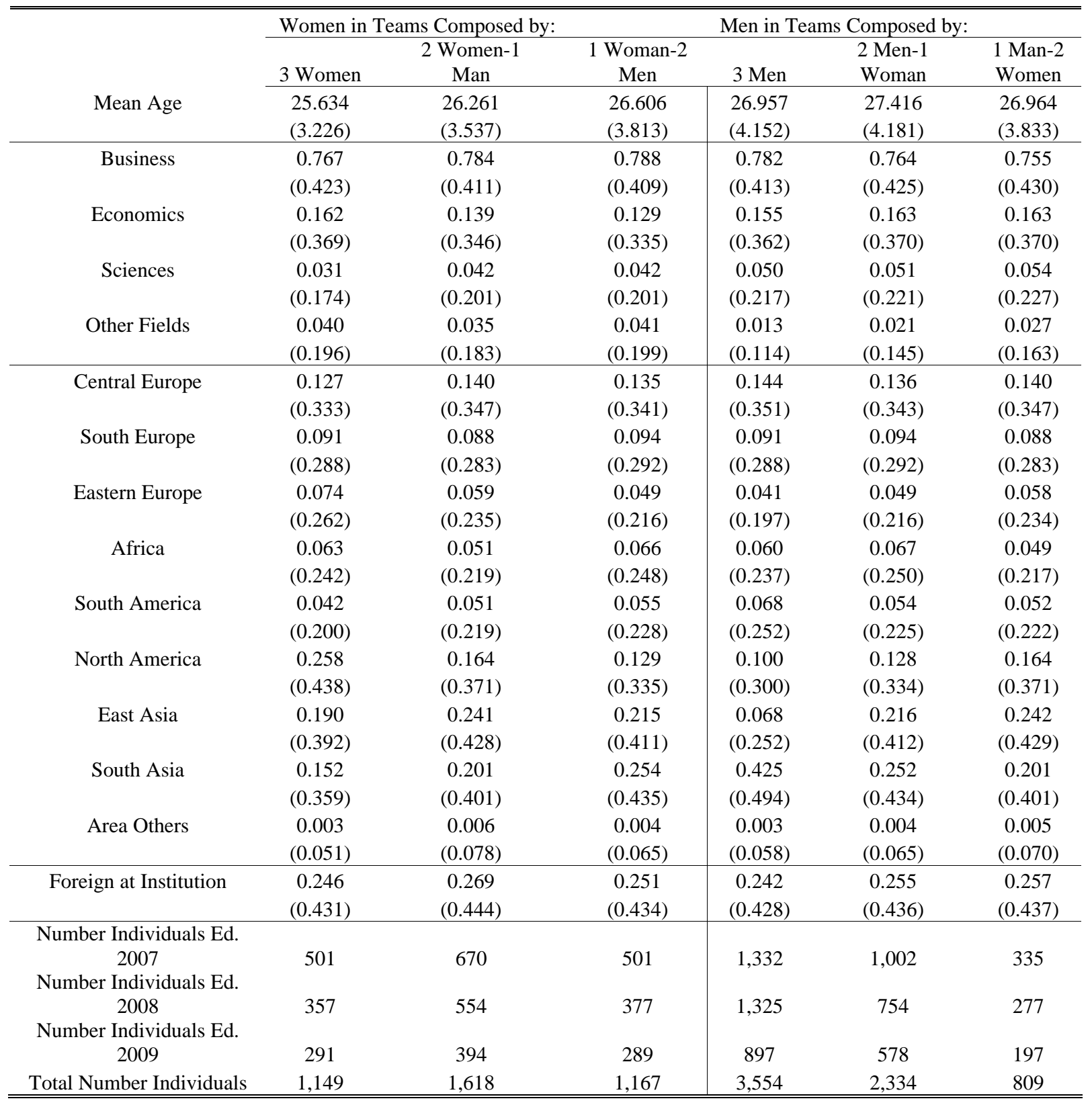

Notes: Business, Economics, Sciences and Other Fields are dummy variables representing categories for the fields of study of the individual. Each category takes a value of 1 if the field of study of the individual belongs to that category, and 0 otherwise. Table A.1 reports the classification of fields of study in the four categories. Geographical areas are dummy variables taking a value of 1 if the country of origin of the individual belongs to the respective geographical area, and 0 otherwise. Individuals not reporting a geographical area are collected in Area Others. Table A.2 reports the assignment of countries to the respective geographical areas. Foreign at Institution is a dummy variable giving a value of 1 when the country of origin of the individual does not coincide with the country where the educational institution is located, and a value of 0 otherwise. Standard errors are reported in brackets. 
Table 13: Gender Composition of Teams on Normalized SPI: IV Approach

\begin{tabular}{|c|c|c|c|c|c|c|c|c|}
\hline & \multicolumn{2}{|c|}{ OLS } & \multicolumn{2}{|c|}{ IV1 } & \multicolumn{2}{|c|}{ IV2 } & \multicolumn{2}{|c|}{ IV3 } \\
\hline & $\begin{array}{l}\text { UG } \\
(1) \\
\end{array}$ & $\begin{array}{c}\text { MBA } \\
(2) \\
\end{array}$ & $\begin{array}{l}\text { UG } \\
(3) \\
\end{array}$ & $\begin{array}{c}\text { MBA } \\
(4) \\
\end{array}$ & $\begin{array}{l}\text { UG } \\
(5) \\
\end{array}$ & $\begin{array}{c}\text { MBA } \\
(6) \\
\end{array}$ & $\begin{array}{l}\text { UG } \\
(7) \\
\end{array}$ & $\begin{array}{c}\text { MBA } \\
(8) \\
\end{array}$ \\
\hline M0 & $\begin{array}{c}-0.0201 * * * \\
{[0.00302]}\end{array}$ & $\begin{array}{c}-0.0210^{* * *} \\
{[0.00699]}\end{array}$ & $\begin{array}{c}-0.0273^{* *} \\
{[0.0132]}\end{array}$ & $\begin{array}{c}-0.0434 \\
{[0.0295]}\end{array}$ & $\begin{array}{l}-0.0433 * \\
{[0.0226]}\end{array}$ & $\begin{array}{c}0.0795 \\
{[0.0593]}\end{array}$ & $\begin{array}{c}-0.544^{*} \\
{[0.288]}\end{array}$ & $\begin{array}{c}-0.0035 \\
{[0.0651]}\end{array}$ \\
\hline Constant & $\begin{array}{c}0.660 * * * \\
{[0.0220]}\end{array}$ & $\begin{array}{c}0.504 * * * \\
{[0.0321]}\end{array}$ & $\begin{array}{c}0.677 * * * \\
{[0.0244]}\end{array}$ & $\begin{array}{c}0.530 * * * \\
{[0.0365]}\end{array}$ & $\begin{array}{c}0.684 * * * \\
{[0.0298]}\end{array}$ & $\begin{array}{c}0.484 * * * \\
{[0.0474]}\end{array}$ & $\begin{array}{c}0.901^{* * *} \\
{[0.140]}\end{array}$ & $\begin{array}{c}0.476 * * * \\
{[0.0369]}\end{array}$ \\
\hline Observations & 8998 & 3482 & 8998 & 3482 & 8998 & 3482 & 4184 & 2440 \\
\hline
\end{tabular}

Notes:* denotes significance at the $10 \%$ level, ** denotes significance at the $5 \%$ and $* * *$ denotes significance at the $1 \%$ level. All columns control for observable characteristics (as listed in Table 6), as well as controls for year and zone fixed effects. The dependent variable, SPI, in all columns is standardized by subtracting the minimum value of SPI from the actual SPI and dividing this by the difference between the maximum and minimum SPI. The variable, M0, takes the value of one when all members of the team are women and zero otherwise. IV1 is the ratio of participating women to men in a given year at the university level. IV2 is the change in the ratio of participating women to men from one year to another at the university level. IV3 is the ratio of women to men at the country level. Data for IV3 is taken from the World Development Indicators database (World Bank, 2008). 


\section{Appendix}

Table A.1-Classification of Fields of Study in Categories

\begin{tabular}{|c|c|c|c|c|c|c|c|c|c|c|c|}
\hline \multicolumn{3}{|c|}{ Business } & \multicolumn{3}{|c|}{ Economics } & \multicolumn{3}{|c|}{ Science } & \multicolumn{3}{|c|}{ Other Fields } \\
\hline Field & Under & MBA & Field & Under & MBA & Field & Under & MBA & Field & Under & MBA \\
\hline Management & 7,981 & 5,927 & Economics & 4,314 & 491 & Sciences & 2,029 & 144 & Communication & 496 & 128 \\
\hline Marketing & 2,755 & 1,875 & Finance & 3,228 & 1,135 & Computer science & 1,167 & 184 & Language & 472 & 30 \\
\hline Accounting & 2,052 & 143 & & & & Physics/Chemistry & 722 & 67 & Law & 422 & 70 \\
\hline Logistics & 545 & 117 & & & & Psychosociology & 126 & 16 & Liberal Arts & 217 & 36 \\
\hline $\begin{array}{l}\text { Human } \\
\text { resources }\end{array}$ & 282 & 101 & & & & Beuty & 113 & 29 & & & \\
\hline Sales & 120 & 76 & & & & Medicine & 108 & 27 & & & \\
\hline Secretary & 27 & 4 & & & & Pharmacy & 90 & 25 & & & \\
\hline & & & & & & Veterinary & 18 & 6 & & & \\
\hline Total: & 13,762 & 8,243 & Total: & 7,542 & 1,626 & Total: & 4,373 & 498 & Total: & 1,607 & 264 \\
\hline
\end{tabular}

Table A.2-Geographical areas

“Central Europe” (826;491): Germany, Belgium, France, Ireland, Luxembourg, Monaco, Holland, United Kingdom.

“South Europe” (674;324): Spain, Italy, Portugal, San Marino, Austria, Switzerland.

“Eastern Europe” (1003; 180): Albania, Bulgaria, Czech Republic, Denmark, Finland, Georgia, Greece, Hungary, Latvia, Lithuania, Norway, Poland, Romania, Russian Federation, Serbia and Montenegro, Slovakia, Slovenia, Sweden, Ukraine.

“Africa” (799; 211): Algeria, Armenia, Cameroon, Egypt, Iran (Islamic Republic of), Israel, Jordan, Kenya, Lebanon, Turkey, Mauritius, Morocco, Sudan, Tunisia, United Arab Emirates, Zambia.

“South America” (561; 202): Argentina, Bolivia, Brazil, Chile, Colombia, Costa Rica, Cuba, Ecuador, Guatemala, Jamaica, Mexico, Paraguay, Peru, Puerto Rico, Uruguay, Venezuela.

“North America” (350; 499): Canada, United States, Australia, New Zealand.

“East Asia” (3284; 601): China, South Korea, Hong Kong, Japan, Taiwan.

“South Asia” (1573; 1021): Afghanistan, Azerbaijan, Bangladesh, Bhutan, India, Indonesia, Kazakhstan, Malaysia, Mongolia, Pakistan, the Philippines, Singapore, Thailand, Uzbekistan, Vietnam.

Notes: The categories correspond to the classification of countries used in the game. The labels of the categories are determined by the countries in the respective category with the highest number of teams in the game. The number of undergraduate and MBA teams per geographical area are reported in brackets. 